\title{
The control of hydrogen sulfide on benthic iron and cadmium fluxes in the oxygen minimum zone off Peru
}

\author{
Anna Plass, Christian Schlosser, Stefan Sommer, Andrew W. Dale, Eric P. Achterberg, and Florian Scholz \\ GEOMAR Helmholtz Centre for Ocean Research Kiel, Wischhofstraße 1-3, 24148 Kiel, Germany
}

Correspondence: Anna Plass (aplass@geomar.de) and Florian Scholz (fscholz@geomar.de)

Received: 25 September 2019 - Discussion started: 15 October 2019

Revised: 26 May 2020 - Accepted: 9 June 2020 - Published: 15 July 2020

\begin{abstract}
Sediments in oxygen-depleted marine environments can be an important sink or source of bio-essential trace metals in the ocean. However, the key mechanisms controlling the release from or burial of trace metals in sediments are not exactly understood. Here, we investigate the benthic biogeochemical cycling of iron $(\mathrm{Fe})$ and cadmium $(\mathrm{Cd})$ in the oxygen minimum zone off Peru. We combine bottom water and pore water concentrations, as well as benthic fluxes determined from pore water profiles and from in situ benthic chamber incubations, along a depth transect at $12^{\circ} \mathrm{S}$. In agreement with previous studies, both concentration-depth profiles and in situ benthic fluxes indicate a release of Fe from sediments to the bottom water. Diffusive Fe fluxes and Fe fluxes from benthic chamber incubations ( -0.3 to $-17.5 \mathrm{mmol} \mathrm{m}^{-2} \mathrm{yr}^{-1}$ ) are broadly consistent at stations within the oxygen minimum zone, where the flux magnitude is highest, indicating that diffusion is the main transport mechanism of dissolved Fe across the sediment-water interface. The occurrence of mats of sulfuroxidizing bacteria on the seafloor represents an important control on the spatial distribution of Fe fluxes by regulating hydrogen sulfide $\left(\mathrm{H}_{2} \mathrm{~S}\right)$ concentrations and, potentially, $\mathrm{Fe}$ sulfide precipitation within the surface sediment. Rapid removal of dissolved $\mathrm{Fe}$ after its release to anoxic bottom waters hints at oxidative removal by nitrite and interactions with particles in the near-bottom water column. Benthic flux estimates of $\mathrm{Cd}$ suggest a flux into the sediment within the oxygen minimum zone. Fluxes from benthic chamber incubations (up to $22.6 \mu \mathrm{mol} \mathrm{m} \mathrm{m}^{-2} \mathrm{yr}^{-1}$ ) exceed diffusive fluxes $\left(<1 \mu \mathrm{mol} \mathrm{m}{ }^{-2} \mathrm{yr}^{-1}\right)$ by a factor of more than 25 , indicating that downward diffusion of $\mathrm{Cd}$ across the sediment-water interface is of subordinate importance for $\mathrm{Cd}$ removal from benthic chambers. As Cd removal in benthic chambers co-
\end{abstract}

varies with $\mathrm{H}_{2} \mathrm{~S}$ concentrations in the pore water of surface sediments, we argue that $\mathrm{Cd}$ removal is mediated by precipitation of cadmium sulfide (CdS) within the chamber water or directly at the sediment-water interface. A mass balance approach, taking the contributions of diffusive and chamber fluxes as well as Cd delivery with organic material into account, suggests that CdS precipitation in the near-bottom water could make an important contribution to the overall $\mathrm{Cd}$ mass accumulation in the sediment solid phase. According to our results, the solubility of trace metal sulfide minerals $(\mathrm{Cd} \ll \mathrm{Fe})$ is a key factor controlling trace metal removal and, consequently, the magnitude and the temporal and spatial heterogeneity of sedimentary fluxes. We argue that, depending on their sulfide solubility, sedimentary source or sink fluxes of trace metals will change differentially as a result of declining oxygen concentrations and the associated expansion of sulfidic surface sediments. Such a trend could cause a change in the trace metal stoichiometry of upwelling water masses with potential consequences for marine ecosystems in the surface ocean.

\section{Introduction}

\subsection{Scientific rationale}

The world's oceans are losing oxygen (e.g., Keeling et al., 2010; Stramma et al., 2010; Helm et al., 2011). In total, around $2 \%$ of the world ocean's oxygen has been lost over the past 5 decades (Schmidtko et al., 2017), and an expansion of oxygen minimum zones (OMZs) in the tropical oceans has been documented over the same time span (Stramma et al., 2008). The biogeochemical cycling of several nutrient-type trace metals (TMs) is likely to be particularly susceptible to 
changing oxygen concentrations as they occur in different oxidation states (e.g., iron, $\mathrm{Fe}$; manganese, $\mathrm{Mn}$; and cobalt, Co) and/or precipitate as sulfide mineral in anoxic-sulfidic environments (e.g., Fe; zinc, $\mathrm{Zn}$; and cadmium, Cd; listed in the order of decreasing sulfide solubility). However, with the exception of Fe (Dale et al., 2015a; Lohan and Bruland, 2008; Rapp et al., 2019; Schlosser et al., 2018; Scholz et al., 2014a), little information is available on how other TM fluxes will respond to ocean deoxygenation. As certain TMs are essential for the growth of marine organisms (e.g., Fe; Mn; Co; nickel, Ni; Zn; and Cd), TM availability can (co-)limit primary productivity and, therefore, affect oceanic carbon sequestration through the biological pump (Saito et al., 2008; Moore et al., 2013; Morel et al., 2014). As a consequence, a better understanding of how TMs respond to low oxygen conditions is essential for predicting how marine ecosystems and the carbon cycle will evolve in the future ocean, with modeling scenarios predicting a continuation of ocean deoxygenation (Bopp et al., 2002; Oschlies et al., 2008; Keeling et al., 2010).

Marine sediments are an important source or sink of TMs to the ocean under low oxygen conditions (Böning et al., 2004; Brumsack, 2006; Scor Working Group, 2007; Severmann et al., 2010; Noble et al., 2012; Biller and Bruland, 2013; Conway and John, 2015b; Klar et al., 2018). In the OMZ off the coast of Peru, substantial fluxes of reduced $\mathrm{Fe}$ and other TMs across the sediment-bottom water interface have been documented (Noffke et al., 2012; Scholz et al., 2016) or inferred (Hawco et al., 2016). While a number of studies have addressed biogeochemical processes that lead to benthic Fe release, the key biogeochemical processes and conditions that control the sedimentary release or burial of other TMs in open marine systems are still poorly constrained. Moreover, a detailed picture of removal or stabilization processes and rates that take place in the highly dynamic water layer overlying the seafloor is lacking.

In this article, we compare the benthic biogeochemical cycling of $\mathrm{Fe}$ and $\mathrm{Cd}$. It has been established that the Peruvian OMZ represents a source of dissolved Fe to the ocean (Noffke et al., 2012; Fitzsimmons et al., 2016; John et al., 2018). In contrast, earlier studies have demonstrated that OMZs represent a sink for Cd (Janssen et al., 2014; Böning et al., 2004). Because of their contrasting tendency to form sulfide minerals and different supply pathways to the sediment, $\mathrm{Fe}$ and $\mathrm{Cd}$ can serve as prototypes to provide information about how sedimentary fluxes of different TMs may respond to declining oxygen concentrations. Under more reducing conditions, the mobility of TMs can either be enhanced or diminished, e.g., through precipitation of sulfide minerals that are buried in the sediments (e.g., Westerlund et al., 1986; Rigaud et al., 2013; Olson et al., 2017). Increased burial or release of TMs at the seafloor can have an impact on the amplitude of primary productivity, especially at the eastern ocean boundaries where the near-bottom water column is connected to the surface ocean via upwelling. Moreover, as the inventories of TMs in the ocean are generally dependent on the respective input and output fluxes, changes in the balance between TM recycling and burial can have an impact on oceanic TM reservoirs on longer timescales. By comparing the benthic biogeochemical cycling of $\mathrm{Fe}$ and $\mathrm{Cd}$ across spatial and temporal redox gradients, we aim to provide general constraints on how the stoichiometry of bio-essential TMs in seawater may be affected by ocean deoxygenation.

\subsection{Marine biogeochemistry of iron}

Iron is the most abundant TM in phytoplankton and part of a range of metalloenzymes that are involved in important biological functions, such as photosynthesis or nitrogen fixation (Twining and Baines, 2013). Despite Fe being highly abundant in the continental crust, its low availability limits primary productivity in up to $30 \%$ of the surface ocean area (Moore et al., 2013). This limitation arises from the low solubility of its thermodynamically stable form in oxic waters, $\mathrm{Fe}(\mathrm{III})$. Concentrations can reach up to $\sim 1 \mathrm{nM}$ when Fe(III) is kept in solution through complexation with organic ligands (Rue and Bruland, 1997; Liu and Millero, 2002; Boyd and Ellwood, 2010; Raiswell and Canfield, 2012). The thermodynamically stable form of $\mathrm{Fe}$ under anoxic conditions, $\mathrm{Fe}(\mathrm{II})$, is more soluble; therefore, anoxic waters are typically characterized by higher dissolved Fe concentrations (up to tens of nanomoles; Conway and John, 2014; Vedamati et al., 2014; Fitzsimmons et al., 2016; Schlosser et al., 2018).

Sediments within OMZs are considered to be an important source of dissolved Fe, and some of the highest sedimentary Fe fluxes have been observed in these regions (Severmann et al., 2010; Noffke et al., 2012). Under anoxic conditions, $\mathrm{Fe}(\mathrm{II})$ can be liberated from the sediments into pore waters from $\mathrm{Fe}$-(oxyhydr)oxides through reductive dissolution by microbes or abiotic reduction with hydrogen sulfide $\left(\mathrm{H}_{2} \mathrm{~S}\right)$ (Canfield, 1989). In the absence of oxygen, dissolved $\mathrm{Fe}(\mathrm{II})$ escapes the rapid re-oxidation and subsequent (oxyhydr)oxide precipitation and can, therefore, diffuse from pore waters into bottom waters. However, in anoxic OMZs, where denitrification takes place, $\mathrm{Fe}(\mathrm{II})$ can also be re-oxidized with nitrate as a terminal electron acceptor, either mediated by nitrate-reducing microbes or abiotically through reaction with nitrite (Straub et al., 1996; Carlson et al., 2013; Scholz et al., 2016; Heller et al., 2017). The solubility of $\mathrm{Fe}$ in sulfidic, i.e., nitrate- $\left(\mathrm{NO}_{3}^{-}\right)$and nitrite- $\left(\mathrm{NO}_{2}^{-}\right)$depleted, water is relatively high (Rickard et al., 2006), and during sulfidic events dissolved Fe can accumulate in the water column (up to hundreds of nanomoles) due to decreased $\mathrm{Fe}$ oxidation (Scholz et al., 2016) and stabilization as aqueous Fe sulfide complexes and clusters (Schlosser et al., 2018). However, Fe fluxes across the benthic boundary have also been hypothesized to decrease under strongly sulfidic conditions in the surface sediments, when pore waters become oversaturated with respect to Fe monosulfide (Scholz et al., 2014), which is the precursor to pyrite $\left(\mathrm{FeS}_{2}\right)$ (Raiswell and Canfield, 2012). 


\subsection{Marine biogeochemistry of cadmium}

Cadmium is abundant in phytoplankton despite concentrations that are 1 order of magnitude lower than $\mathrm{Fe}$ (Moore et al., 2013; Twining and Baines, 2013). A function for $\mathrm{Cd}$ as a catalytic metal atom in the carbonic anhydrase protein has been found in diatoms (Lane and Morel, 2000), and it can also substitute $\mathrm{Zn}$ and enhance phytoplankton growth under Zn limitation in different phytoplankton species (Price and Morel, 1990; Lee and Morel, 1995; Sunda and Huntsman, 2000; Xu et al., 2008). In marine sediments $\mathrm{Cd}$ can be released from the solid phase to the pore waters through the remineralization of organic matter (Klinkhammer et al., 1982; Collier and Edmond, 1984; Gendron et al., 1986; Gerringa, 1990; Audry et al., 2006; Scholz and Neumann, 2007). After its release to the pore water, $\mathrm{Cd}$ can diffuse across the sediment-water interface. Under anoxic and sulfidic conditions, $\mathrm{Cd}$ is thought to be precipitated as cadmium sulfide (CdS; greenockite) and retained in the sediment (Westerlund et al., 1986; Gobeil et al., 1987; Rosenthal et al., 1995; Audry et al., 2006). Due to its low sulfide solubility, CdS can precipitate at much lower $\mathrm{H}_{2} \mathrm{~S}$ concentrations than $\mathrm{FeS}$ (mackinawite; Morse and Luther, 1999).

Most previous studies have focused on the benthic cycling of $\mathrm{Cd}$ in near-shore and inshore environments such as estuaries and lagoons (e.g., Westerlund et al., 1986; Colbert et al., 2001; Audry et al., 2006; Metzger et al., 2007; Point et al., 2007; Scholz and Neumann, 2007). By contrast, little is known about $\mathrm{Cd}$ cycling in open-marine sedimentary environments, where the redox dynamics and sediment dynamics are different. Previous studies on sedimentary Cd cycling have generally concluded that the flux of organic material and the presence of $\mathrm{H}_{2} \mathrm{~S}$ are the most important factors controlling the balance between $\mathrm{Cd}$ recycling and precipitation and burial (e.g., Westerlund et al., 1986; Colbert et al., 2001; Audry et al., 2006; Metzger et al., 2007; Scholz and Neumann, 2007). Low oxygen regions in the ocean are considered to be an important sink for Cd (Janssen et al., 2014; Conway and John, 2015a; Xie et al., 2019), and sediments below OMZs are highly enriched in Cd (Ragueneau et al., 2000; Böning et al., 2004; Borchers et al., 2005; Muñoz et al., 2012; Little et al., 2015). However, the respective contributions of different $\mathrm{Cd}$ removal mechanisms to $\mathrm{Cd}$ accumulation in the sediment have not been quantified.

\subsection{Study area}

Seasonal upwelling of nutrient-rich waters off the Peruvian coast in austral winter leads to high rates of primary productivity in the photic zone $\left(\sim 300 \mathrm{mmol} \mathrm{C} \mathrm{m}^{-3} \mathrm{~d}^{-1}\right.$; Pennington et al., 2006). The combination of oxygen consumption through the respiration of this organic matter and low oxygen concentrations in water masses that supply upwelling regions leads to the formation of one of the world's most intense OMZs, with complete oxygen consumption in the OMZ core between water depths of $\sim 100$ and $300 \mathrm{~m}$ (Karstensen et al., 2008; Thamdrup et al., 2012). Upon oxygen depletion, $\mathrm{NO}_{3}^{-}$can serve as an electron acceptor for respiration. Therefore, denitrification, dissimilatory reduction of $\mathrm{NO}_{3}^{-}$ to ammonium (DNRA) and anaerobic ammonium oxidation (anammox) with $\mathrm{NO}_{2}^{-}$are important biogeochemical processes within the anoxic and nitrogenous water column (Lam et al., 2009; Lam and Kuypers, 2011; Dalsgaard et al., 2012). The OMZ overlying the Peruvian shelf is a temporally and spatially dynamic system where biogeochemical conditions can range from fully oxic to anoxic and sulfidic. Occasional shelf oxygenation events occur, mostly during El Niño events, and are linked to the propagation of coastal trapped waves (Gutiérrez et al., 2008). During such events, oxygenated water can be found on the upper slope to water depths of 200-300 m (Levin et al., 2002). By contrast, sulfidic events can occur during periods of stagnation, when oxygen, $\mathrm{NO}_{3}^{-}$and $\mathrm{NO}_{2}^{-}$become depleted in the water column due to sluggish ventilation. Once $\mathrm{NO}_{3}^{-}$and $\mathrm{NO}_{2}^{-}$are depleted, chemolithoautotrophic $\mathrm{H}_{2} \mathrm{~S}$ oxidation is impeded. Hydrogen sulfide produced by bacterial sulfate reduction in sediments can then be released to the water column (Schunck et al., 2013) at rates reaching several millimoles per square meter per day (Sommer et al., 2016).

Our sampling campaign (cruises M136 and M137) took place in April and May 2017, during the decline of a coastal El Niño event. A coastal El Niño is a local phenomenon that refers to reduced upwelling and increased sea surface temperatures off the coasts of Peru and Ecuador, typically with heavy rainfall on land. During this event in austral summer, coastal waters off Peru showed a strong positive sea surface temperature anomaly of up to $2-4^{\circ} \mathrm{C}$ (Echevin et al., 2018; Garreaud, 2018). The warming is proposed to be a result of strong local alongshore wind anomalies and equatorial Kelvin waves propagating towards the Peruvian coast (Echevin et al., 2018; Peng et al., 2019).

\section{Methods}

\subsection{Sampling and sample handling}

In this study, data from three different types of samples were combined: (1) pore waters for the determination of benthic diffusive fluxes and to study TM cycling in sediments; (2) benthic chamber incubations, to determine in situ fluxes across the sediment-water interface; and (3) bottom water concentration-depth profiles to determine the fate of TMs in the particle-rich and dynamic near-bottom water column.

The sampling took place during RV Meteor cruises M136 and M137 in austral autumn between April and May 2017. We also compared our data to benthic diffusive Fe(II) fluxes from RV Meteor cruise M92 (data from Schroller-Lomnitz et al., 2019) that took place in austral summer during January 2013. Our sampling stations covered the entire Peruvian shelf 


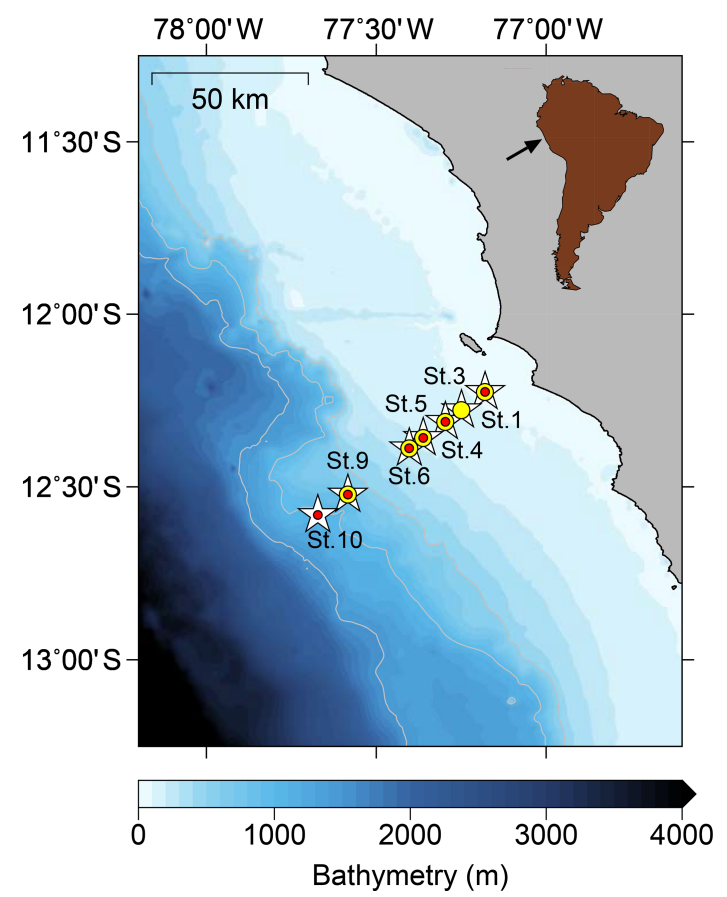

Figure 1. Sampling stations on the Peruvian continental margin during cruises M136 and M137 along a latitudinal depth transect at $12^{\circ} \mathrm{S}$. The sampling stations for pore waters are depicted by white stars, bottom waters are shown using yellow dots, and benthic chamber incubations are denoted by red dots.

and slope across a transect at $12^{\circ} \mathrm{S}$ (Fig. 1) with water depths from 75 to $950 \mathrm{~m}$, thereby including stations above, inside and below the permanent OMZ. Our sampling of pore waters and sample collection from benthic chamber incubations generally followed the methodology described in Noffke et al. (2012).

Short sediment cores of $30-40 \mathrm{~cm}$ in length were retrieved with a multiple corer (MUC). Upon recovery, the cores were directly transferred into the ship's cool room $\left(4^{\circ} \mathrm{C}\right)$. The supernatant bottom water was instantly sampled and filtered through $0.2 \mu \mathrm{m}$ cellulose acetate filters (Sartorius) and acidified to $\mathrm{pH}<1$ with subboiled distilled $\mathrm{HNO}_{3}$. The sediment cores were subsequently sampled in vertical sections in a glove bag under Ar (argon) atmosphere to prevent any contact with oxygen. The sediment samples were centrifuged to separate the pore waters from the sediment solid phase. Pore waters were then filtered in another Ar-filled glove bag through $0.2 \mu \mathrm{m}$ cellulose acetate filters (Sartorius). An $8 \mathrm{~mL}$ aliquot was acidified to $\mathrm{pH}<1$ with subboiled distilled $\mathrm{HNO}_{3}$ and stored in acid-cleaned low-density polyethylene (LDPE) bottles for TM analysis. Another aliquot was taken for the analysis of $\mathrm{H}_{2} \mathrm{~S}$ concentrations. Additional sediment subsamples were collected in pre-weighed cups for water content and porosity determination as well as for $\mathrm{Cd}$ and organic $\mathrm{C}$ concentration measurements in the solid phase.
Benthic landers, constructed from titanium frames, containing two circular benthic chambers for in situ incubations, were deployed on the seafloor (see Sommer et al. 2009 for details). After placement of the lander on the seafloor, the benthic chambers (internal diameter of $28.8 \mathrm{~cm}$ ) were partially driven into the sediment, covering a sediment area of $651.4 \mathrm{~cm}^{2}$. A volume between 12 and $18 \mathrm{~L}$, overlying the first $20-30 \mathrm{~cm}$ of the seafloor, was enclosed in the chamber, depending on the insertion depth of the chamber into the sediment. Prior to the incubation, the seawater contained in the chamber was repeatedly replaced with ambient seawater to replace solutes and flush out particles that might have been mobilized during the insertion of the chamber into the sediment. Over the incubation time of around $32 \mathrm{~h}$, eight consecutive $12 \mathrm{~mL}$ samples were filtered in situ through $0.2 \mu \mathrm{m}$ cellulose acetate filters (Sartorius) via peristaltic pumps and collected in quartz glass tubes. All sampling tubes were acid cleaned prior to use to guarantee a TM clean sampling. After recovery of the lander, the quartz glass tubes were transferred to the laboratory and samples were stored in acid-cleaned LDPE bottles and acidified to $\mathrm{pH}<2$ with subboiled distilled $\mathrm{HNO}_{3}$. Other samples were collected simultaneously for the analysis of nitrogen species. The incubated sediments within the benthic chamber were sampled after the recovery of the lander, and pore waters were extracted to analyze $\mathrm{H}_{2} \mathrm{~S}$ concentrations for comparison with pore water profiles from parallel MUCs.

To determine TM concentrations across the near-bottom water column, water samples were collected at $0.5,1.0,2.0$, 3.0 and $4.0 \mathrm{~m}$ above the seafloor using sampling apparatus attached to the landers. Filter holders with $0.2 \mu \mathrm{m}$ polyethersulfone filters (Supor) were attached at the various depths and connected to sampling tubes that went through peristaltic pumps into gas sampling bags (Tedlar). Sampling at 3.0 and $4.0 \mathrm{~m}$ above the seafloor was realized by attaching the filter holders and tubing to an arm that was automatically unfolded upon placement of the lander at the seafloor. The peristaltic pumps transferred the seawater from the sampling depths into the sampling bags over the same time period as the lander incubations of around $32 \mathrm{~h}$. This resulted in an average sample volume of $1.5 \mathrm{~L}$ for each depth. All filters, tubing and sampling bags were acid cleaned prior to deployment to guarantee a TM clean sampling. Directly after sample retrieval, a $60 \mathrm{~mL}$ aliquot was stored in acid-cleaned LDPE bottles and acidified to $\mathrm{pH}<2$ for TM analysis. Another aliquot was taken for the analysis of silicic acid $\left(\mathrm{Si}(\mathrm{OH})_{4}\right)$.

\subsection{Analytical methods}

Concentrations of $\mathrm{Fe}(\mathrm{II})$ in pore waters were measured onboard directly after sample retrieval by photometry using the ferrozine method (Stookey, 1970). Other geochemical parameters in our different samples were also determined photometrically (U-2001 Hitachi spectrometer) using standard techniques (Grasshoff et al., 1999). Hydrogen sulfide 
concentrations were determined using the methylene blue method, and $\mathrm{Si}(\mathrm{OH})_{4}$ concentrations were determined using a heptamolybdate solution as reagent. Concentrations of nitrogen species were determined by an auto-analyzer (QuAAtro, SEAL Analytical) using sulfanilamide as reagent (Hydes et al., 2010).

For TM analysis of bottom water samples, we followed the procedure described by Rapp et al. (2017), whereby the TMs were pre-concentrated by a fully automated device (SeaFAST). After raising the sample $\mathrm{pH}$ to 6.4 with an ammonium acetate buffer $(1.5 \mathrm{M}), 15 \mathrm{~mL}$ of sample was loaded onto a chelating resin column, where the seawater matrix was rinsed off, before the TMs were collected into $1 \mathrm{~mL}$ elution acid ( $1 \mathrm{M}$ subboiled $\mathrm{HNO}_{3}$ ). Due to the smaller size of pore water samples and samples from benthic lander incubations, a semiautomated device (Preplab, PS Analytical) with a smaller sample loop and, thus, dead volume was used. On this device, sample loading and collection as well as the addition of buffer was done manually. For samples from benthic lander incubations and pore waters, a respective amount of 3 and $1 \mathrm{~mL}$ was needed for pre-concentration. The samples were diluted with deionized water (Milli-Q, Millipore) to increase the sample volume to $5 \mathrm{~mL}$ for samples from benthic chamber incubations and to $3 \mathrm{~mL}$ for pore waters. The preconcentrated samples were measured by inductively coupled plasma mass spectrometry (HR-ICP-MS; Thermo Fisher ELEMENT XR), and TM concentrations were quantified by isotope dilution. The detection limits were $28.8 \mathrm{pM}$ for $\mathrm{Fe}$ and $0.8 \mathrm{pM}$ for Cd (Rapp et al., 2017). Accuracies for replicate measurements of reference seawater certified for TMs are listed in Table 1.

For the calculation of sedimentary Cd enrichments $\left(\mathrm{Cd}_{\mathrm{xs}}\right)$, $\mathrm{Cd}$ and aluminum ( $\mathrm{Al})$ contents in sediments were determined following total digestions of freeze-dried and ground sediment samples. The sediment was digested in $40 \% \mathrm{HF}$ (Suprapure), $65 \% \mathrm{HNO}_{3}$ (Suprapure) and $60 \% \mathrm{HClO}_{4}$ (Suprapure). Concentrations were measured by inductively coupled plasma optical emission spectrometry (ICP-OES; VARIAN 720-ES). The reference standard MESS was used to check the digestion procedure. The accuracy was $\pm 0.3 \%$ for $\mathrm{Cd}$ and $\pm 1.3 \%$ for $\mathrm{Al}$ (MESS-3 Cd: $0.24 \pm 0.01 \mu \mathrm{g} \mathrm{g}^{-1}$, recommended value $0.24 \pm 0.01 \mu \mathrm{g} \mathrm{g}^{-1}$; MESS-3 Al: $8.59 \pm$ $0.11 \mu \mathrm{g} \mathrm{g}^{-1}$, recommended value $8.59 \pm 0.23 \mu \mathrm{g} \mathrm{g}^{-1}$ ).

The organic carbon content in the sediment was determined using an elemental analyzer (Euro EA) after removal of inorganic carbon with $0.25 \mathrm{mM} \mathrm{HCl}$. The precision of the measurement was $\pm 1 \%$.

\subsection{Diffusive flux calculations}

Benthic diffusive fluxes $\left(F_{\mathrm{D}}\right)$ were determined with Fick's first law of diffusion using concentration gradients between the uppermost pore water sample $(0-1 \mathrm{~cm})$ and the overlying bottom water $(\mathrm{d} C / \mathrm{d} x)$ (Boudreau, 1997):

$F_{\mathrm{D}}=-\Phi D_{\text {sed }}(\mathrm{d} C / \mathrm{d} x)$

The effective molecular diffusion coefficients of $\mathrm{Fe}$ and $\mathrm{Cd}$ for sediments $\left(D_{\text {sed }}\right)$ were calculated from the molecular diffusion coefficient in seawater $\left(D_{\mathrm{sw}}\right)$ under standard conditions (Li and Gregory, 1974) by adjusting it to in situ temperature, pressure and salinity applying the Stokes-Einstein equation. We determined the diffusion coefficients for sediments as follows:

$D_{\text {sed }}=D_{\text {sw }} / \theta^{2}$

Tortuosity $(\theta)$ was calculated from porosity $(\Phi)$ as follows (Boudreau, 1997):

$\theta^{2}=1-\ln \left(\phi^{2}\right)$

Positive values represent a flux from the bottom water into the sediment pore water, and negative values represent a flux from the sediment pore water into the bottom water. All input values for the diffusive flux calculations are listed in Tables S1 and S2 in the Supplement.

Due to the coarse resolution of our pore water profiles and the steep gradients between the uppermost pore water and bottom water sample (see close-up profiles, Figs. S1 and S2 in the Supplement), we chose to follow previous studies (Pakhomova et al., 2007; Noffke et al., 2012; Scholz et al., 2016, 2019; Lenstra et al., 2019) and calculate diffusive benthic fluxes based on a two-point concentration gradient. Including deeper samples in a linear regression or applying more advanced curve fitting methods would reduce the statistical uncertainty but would fail to capture the sharp concentration gradients at the sediment surface and, thus, lead to erroneous flux estimates (cf. Shibamoto and Harada, 2010).

The fluxes from benthic lander incubations were calculated by fitting a linear regression to the concentration change over time. The relevant equations are listed along with the coefficients of determination $\left(R^{2}\right)$ in Table S4. Concentration changes over time were converted to fluxes by considering the water volume enclosed in the benthic chamber, which was estimated for each deployment from the insertion depth of the benthic chamber into the sediment. The uncertainties of fluxes were estimated by propagating the uncertainties of the linear regressions. Following previous studies (e.g., Friedrich et al., 2002; Lenstra et al., 2019), only fluxes where the linear regression had an $R^{2}$ value greater than 0.3 are reported in Tables 2 and 3.

\section{Results}

\subsection{Biogeochemical conditions in the water column}

Due to the particular atmospheric and oceanographic conditions (the decline of a coastal El Niño) during our sampling 
Table 1. Accuracy of replicate concentration measurements $(n=7)$ of certified reference seawater for trace metals NASS-7 and CASS- 6 by inductively coupled plasma mass spectrometry (ICP-MS).

\begin{tabular}{rrrrr}
\hline & $\begin{array}{r}\text { NASS-7 } \\
\text { certified value }\end{array}$ & $\begin{array}{r}\text { NASS-7 } \\
\text { measured value }\end{array}$ & $\begin{array}{r}\text { CASS-6 } \\
\text { certified value }\end{array}$ & $\begin{array}{r}\text { CASS-6 } \\
\text { measured value }\end{array}$ \\
\hline $\mathrm{Fe}\left(\mu \mathrm{g} \mathrm{L}^{-1}\right)$ & $0.351 \pm 0.026$ & $0.352 \pm 0.017$ & $1.56 \pm 0.12$ & $1.56 \pm 0.03$ \\
$\mathrm{Cd}\left(\mu \mathrm{g} \mathrm{L}^{-1}\right)$ & $0.0161 \pm 0.0016$ & $0.0162 \pm 0,0024$ & $0.0217 \pm 0.0018$ & $0.0216 \pm 0.0016$ \\
\hline
\end{tabular}

campaign (cruises M136 and M137), the water column overlying the Peruvian shelf was oxygenated. Oxygen concentrations were $>20 \mu \mathrm{M}$ in the water column down to a water depth of around $100 \mathrm{~m}$. However, bottom water oxygen concentrations directly above the seafloor, measured using optodes attached to lander, were below the detection limit $(>1 \mu \mathrm{M})$ at the shallowest station (Station 1). The OMZ, with $\mathrm{O}_{2}$ concentrations $<5 \mu \mathrm{M}$, extended from a water depth of around 120 to $400 \mathrm{~m}$. The water column within the OMZ was nitrogenous (i.e., $\mathrm{NO}_{3}^{-}$reducing) as indicated by the presence of $\mathrm{NO}_{2}^{-}(\geq 4 \mu \mathrm{M})$, which is an intermediate product of denitrification (Zumft, 1997). Oxygen gradually increased to $>50 \mu \mathrm{M}$ below $400 \mathrm{~m}$ towards a water depth of $950 \mathrm{~m}$ (Fig. 2). As we will compare some of our data to those of an earlier cruise (M92), the corresponding oxygen distribution across the Peruvian continental margin is shown for comparison (Fig. 2).

\subsection{Bottom water, pore water and benthic flux data}

\subsubsection{Iron}

Iron concentrations in near-bottom waters decreased from near-shore to offshore stations, from more than $100 \mathrm{nM}$ at the shallowest shelf station at a water depth of $75 \mathrm{~m}$ (Station 1) to $6 \mathrm{nM}$ at a water depth of $750 \mathrm{~m}$ (Station 9; Fig. 3). At a number of stations within the OMZ (stations 3 and 4), vertical concentration gradients were observed. Here Fe concentrations decreased by $15-20 \mathrm{nM}$ from 0.5 to $4 \mathrm{~m}$ above the seafloor. Multiple sampling at the shallowest shelf station (Station 1) revealed that $\mathrm{Fe}$ concentrations were temporally variable and ranged from $\sim 100 \mathrm{nM}$ at the end of April to less than $60 \mathrm{nM}$ at the end of May 2017.

Concentrations of $\mathrm{Fe}(\mathrm{II})$ in pore waters were highest (up to a few micromoles) in the upper $5-10 \mathrm{~cm}$ of the sediment cores. Deeper in the sediment cores, concentrations decreased to around or below $0.2 \mu \mathrm{M}$ (Fig. 4). At all stations, sharp concentration gradients between the uppermost pore water and the bottom water sample were observed, with higher concentrations in pore waters at the sediment surface (micromoles) than in the overlying bottom water (nanomoles). This observation implies a diffusive flux from pore waters into bottom waters. The steepest concentration gradients across the sediment-water interface were observed within the OMZ. The highest Fe(II) concentrations at the sediment surface $(>6 \mu \mathrm{M})$ were observed at Station $4(145 \mathrm{~m}$ water depth). At this station, the benthic diffusive flux into the bottom waters was also highest at $-17.5 \mathrm{mmol} \mathrm{m}^{-2} \mathrm{yr}^{-1}$. The lowest diffusive fluxes of 0.0 (due to concentrations below the detection limit) and $-0.3 \mathrm{mmol} \mathrm{m}^{-2} \mathrm{yr}^{-1}$ were observed on the upper slope below the OMZ at stations 9 and 10 , respectively (Table 2). An accumulation of $\mathrm{H}_{2} \mathrm{~S}$ in pore waters coincided with a depletion of $\mathrm{Fe}(\mathrm{II})$ concentrations (Fig. 4). At Station 1, we observed the highest $\mathrm{H}_{2} \mathrm{~S}$ concentrations throughout the core and, in particular, at the sediment surface, with maximum concentrations reaching more than $4 \mathrm{mM}$. At stations below the OMZ (stations 9 and 10), no $\mathrm{H}_{2} \mathrm{~S}$ was detected within pore waters (Fig. 4).

Iron concentrations inside the benthic chambers reached maximum values of more than $300 \mathrm{nM}$. At stations 4 and 6 , located inside the OMZ, concentrations in the chambers increased in a linear way during the incubation. At stations above and below the OMZ, we did not observe a similar trend over time. For comparison with diffusive fluxes, we estimated benthic $\mathrm{Fe}$ fluxes from linear regressions of $\mathrm{Fe}$ concentrations versus time (Table 2). We also calculated the theoretical concentration gradients over time in the benthic chambers based on our diffusive flux estimates (Fig. 5). At some stations the incubation data were largely consistent in direction and slope with the diffusive fluxes. In particular, at stations 4 and 6 inside the OMZ, where the highest diffusive fluxes of -17.5 and $-8.0 \mathrm{mmol} \mathrm{m}^{-2} \mathrm{yr}^{-1}$ were observed, expected and observed concentration gradients were in good agreement. At these stations the highest $R^{2}$ for the linear regressions of the concentration change over the incubation time were also calculated (Station 4: $R^{2}=0.7$; Station 6: $R^{2}=0.5$; Table S4). At stations below the OMZ, diffusive fluxes of less than $1 \mathrm{mmol} \mathrm{m}^{-2} \mathrm{yr}^{-1}$ were too low to be detected over the incubation period of $32 \mathrm{~h}$.

\subsubsection{Cadmium}

In near-bottom waters $\mathrm{Cd}$ concentrations increased with distance from the coast, from $0.4 \mathrm{nM}$ at the shallowest station at a water depth of $75 \mathrm{~m}$ (Station 1) to $1.1 \mathrm{nM}$ below the OMZ at a water depth of $750 \mathrm{~m}$ (Station 9). Cadmium concentrations were constant at each station between 0.5 and $4 \mathrm{~m}$ above the seafloor (Fig. 3).

Cadmium concentrations in pore waters ranged between 0.1 and $2 \mathrm{nM}$ (Fig. 6). Within the OMZ, bottom water concentrations were higher than concentrations in pore water at 
Table 2. Comparison of benthic diffusive Fe(II) fluxes out of the sediment and geochemical bottom water conditions between M136-M137 and M92 on the Peruvian shelf. Fluxes during M92 correspond to similar depth (see Fig. 9).

\begin{tabular}{|c|c|c|c|c|c|c|c|c|}
\hline Station & M136-M137 & M136-M137 & M136-M137 & M136-M137 & M136-M137 & M136-M137 & M92 & M92 \\
\hline & $\begin{array}{l}\text { Water } \\
\text { depth }\end{array}$ & Latitude & Longitude & $\begin{array}{l}\text { Water column } \\
\text { condition }\end{array}$ & $\begin{array}{r}\mathrm{Fe}(\mathrm{II}) \text { flux } \\
\text { diffusive }\end{array}$ & $\begin{array}{r}\text { Fe flux benthic } \\
\text { chamber }\end{array}$ & $\begin{array}{l}\text { Water column } \\
\text { condition }\end{array}$ & $\begin{array}{l}\mathrm{Fe} \text { (II) flux } \\
\text { diffusive* }\end{array}$ \\
\hline & (m) & (S) & $(\mathrm{W})$ & & $\begin{array}{r}\left(\mathrm{mmol} \mathrm{m}^{-2}\right. \\
\left.\mathrm{yr}^{-1}\right)\end{array}$ & $\begin{array}{r}\left(\mathrm{mmol} \mathrm{m}^{-2}\right. \\
\left.\mathrm{yr}^{-1}\right)\end{array}$ & & $\begin{array}{r}\left(\mathrm{mmol} \mathrm{m}^{-2}\right. \\
\left.\mathrm{yr}^{-1}\right)\end{array}$ \\
\hline 1 & 75 & $12^{\circ} 13.52$ & $77^{\circ} 10.93$ & $\mathrm{O}_{2}<5 \mu \mathrm{M}$ & -2.56 & - & Slightly sulfidic & -22.69 \\
\hline 3 & 130 & $12^{\circ} 16.68$ & $77^{\circ} 14.95$ & Nitrogenous & -0.81 & - & Slightly sulfidic & -3.16 \\
\hline 4 & 145 & $12^{\circ} 18.71$ & $77^{\circ} 17.80$ & Nitrogenous & -17.45 & $-8.57 \pm 2.18$ & Nitrogenous & -5.77 \\
\hline 5 & 195 & $12^{\circ} 21.50$ & $77^{\circ} 21.70$ & Nitrogenous & -2.49 & - & Nitrogenous & -1.51 \\
\hline 6 & 245 & $12^{\circ} 23.30$ & $77^{\circ} 24.82$ & Nitrogenous & -7.96 & $-5.43 \pm 2.36$ & Nitrogenous & -10.20 \\
\hline 9 & 750 & $12^{\circ} 31.35$ & $77^{\circ} 35.01$ & $\mathrm{O}_{2}>5 \mu \mathrm{M}$ & 0.00 & $-6.11 \pm 3.12$ & $\mathrm{O}_{2}>5 \mu \mathrm{M}$ & 0.00 \\
\hline 10 & 950 & $12^{\circ} 34.90$ & $77^{\circ} 40.32$ & $\mathrm{O}_{2}>5 \mu \mathrm{M}$ & -0.26 & - & $\mathrm{O}_{2}>5 \mu \mathrm{M}$ & -0.12 \\
\hline
\end{tabular}

* Data from Schroller-Lomnitz et al., 2019.

Table 3. Comparison of sedimentary Cd excess compared with the lithogenic background and the contribution of Cd delivery to the sediment via different pathways: (1) diffusion across the sediment-water interface and cadmium sulfide (CdS) precipitation within the sediment; (2) Cd incorporation by phytoplankton and delivery to the sediment with organic matter; (3) CdS precipitation in the water column and particulate delivery to the sediment.

\begin{tabular}{|c|c|c|c|c|c|c|c|}
\hline Station & $\begin{array}{l}\text { Water } \\
\text { depth }\end{array}$ & $\begin{array}{l}\text { Cd excess } \\
\text { sediment }^{\mathrm{a}}\end{array}$ & $\begin{array}{l}\text { (1) Cd flux } \\
\text { diffusive }\end{array}$ & $\begin{array}{r}\text { Cd flux benthic } \\
\text { chamber }\end{array}$ & $\begin{array}{l}\mathrm{H}_{2} \mathrm{~S} \text { in surface } \\
\text { sediment below } \\
\text { benthic chamber }\end{array}$ & $\begin{array}{l}\text { (2) Cd from } \\
\text { organic matter }\end{array}$ & $\begin{array}{r}\text { (3) } \mathrm{CdS} \\
\text { precipitation in } \\
\text { water column }^{\mathrm{c}}\end{array}$ \\
\hline & (m) & $\left(\mu \mathrm{mol} \mathrm{m}{ }^{-2} \mathrm{yr}^{-1}\right)$ & $\left(\mu \mathrm{mol} \mathrm{m}{ }^{-2} \mathrm{yr}^{-1}\right)$ & $\left(\mu \mathrm{mol} \mathrm{m}{ }^{-2} \mathrm{yr}^{-1}\right)$ & $(\mu \mathrm{M})$ & $\left(\mu \mathrm{mol} \mathrm{m}{ }^{-2} \mathrm{yr}^{-1}\right)$ & $\left(\mu \mathrm{mol} \mathrm{m}{ }^{-2} \mathrm{yr}^{-1}\right)$ \\
\hline 1 & 75 & 248.87 & -1.85 & $(-3109.5)^{d}$ & 641.02 & $8.34-49.04$ & $199.83-240.53$ \\
\hline 3 & 130 & 153.41 & 0.83 & - & - & $4.87-17.40$ & $135.19-147.72$ \\
\hline 4 & 145 & 35.07 & 0.54 & $13.4 \pm 1.05$ & 1.30 & $1.55-6.48$ & $28.07-32.99$ \\
\hline 5 & 195 & 44.76 & 0.63 & $22.6 \pm 3.24$ & 9.52 & $5.71-7.71$ & $36.36-38.36$ \\
\hline 6 & 245 & 35.15 & 0.55 & $21.2 \pm 3.31$ & 0.40 & $3.60-6.54$ & $28.06-31.00$ \\
\hline 9 & 750 & 4.44 & -0.30 & $0.00 \pm 0.02$ & 0.00 & $1.48-3.21$ & $1.23-2.96$ \\
\hline 10 & 950 & - & - & - & 0.00 & - & - \\
\hline
\end{tabular}

${ }^{a}$ Calculated following Brumsack (2006) and multiplied by the mass accumulation rate for each site (Dale et al., 2015b). ${ }^{\mathrm{b}}$ Determined by the multiplication of the Cd/C ratio in average phytoplankton (Moore et al., 2013) with particulate organic carbon rain rates (maximum values) and organic carbon accumulation rates (minimum values) for each individual site (data from Dale et al., 2015b). ${ }^{\mathrm{c}}$ Remainder of the Cd excess in sediment after the subtraction of diffusive and minimum and maximum organic Cd sources. ${ }^{\mathrm{d}}$ Flux calculated from the concentration difference between the bottom water $(0.5 \mathrm{~m})$ and the first sample from the benthic chamber incubation (taken after $0.25 \mathrm{~h}$ ).

the sediment surface $(0-1 \mathrm{~cm})$, indicating a downward diffusive flux into the sediments. The benthic diffusive fluxes inside the OMZ were on the order of $0.6-0.8 \mu \mathrm{mol} \mathrm{m}^{-2} \mathrm{yr}^{-1}$ (Table 3). In contrast, at stations 1 and 9 an upward-directed concentration gradient was observed, indicating a diffusive flux from the sediments into bottom waters. The upward diffusive flux was $-1.9 \mu \mathrm{mol} \mathrm{m}^{-2} \mathrm{yr}^{-1}$ above the permanent OMZ and $-0.2 \mu \mathrm{mol} \mathrm{m}^{-2} \mathrm{yr}^{-1}$ below the OMZ (Table 3). Pore water $\mathrm{Cd}$ concentrations at greater sediment depths were mostly higher than bottom water concentrations. In some cases (stations 3 and 4), elevated pore water $\mathrm{Cd}$ concentrations (up to $2 \mathrm{nM}$ ) coincided with elevated $\mathrm{H}_{2} \mathrm{~S}$ concentrations (a few hundred micromoles).

In the benthic chambers, three different $\mathrm{Cd}$ trends were observed (Fig. 7). Above the permanent OMZ (Station 1), $\mathrm{Cd}$ concentrations in the chambers were low $(<0.2 \mathrm{nM})$ throughout the incubation period, indicating no $\mathrm{Cd}$ flux. At sites within the OMZ (stations 4, 5 and 6), concentrations decreased from $\sim 0.6$ to $0.3 \mathrm{nM}$ over the course of the incubation. Below the OMZ (stations 9 and 10), Cd concentrations in the chamber were high $(\sim 1 \mathrm{nM})$ and remained constant or increased slightly during the incubation. At sites within the OMZ, Cd removal within the chamber was nearlinear (stations 4, 5 and 6: $R^{2}=\geq 0.9$; Table S4), which translates to a removal flux of $13-23 \mu \mathrm{mol} \mathrm{m}^{-2} \mathrm{yr}^{-1}$. The Cd removal fluxes in benthic chambers were more than 1 order of magnitude higher than diffusive benthic fluxes (0.6$0.8 \mu \mathrm{mol} \mathrm{m} \mathrm{yr}^{-1}$; Table 3). 

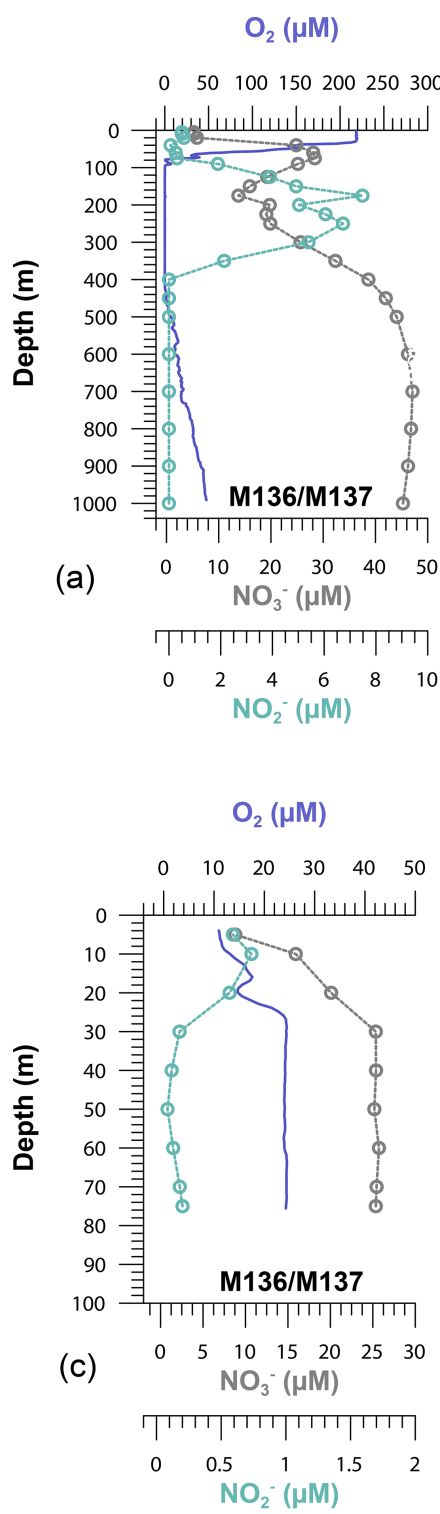
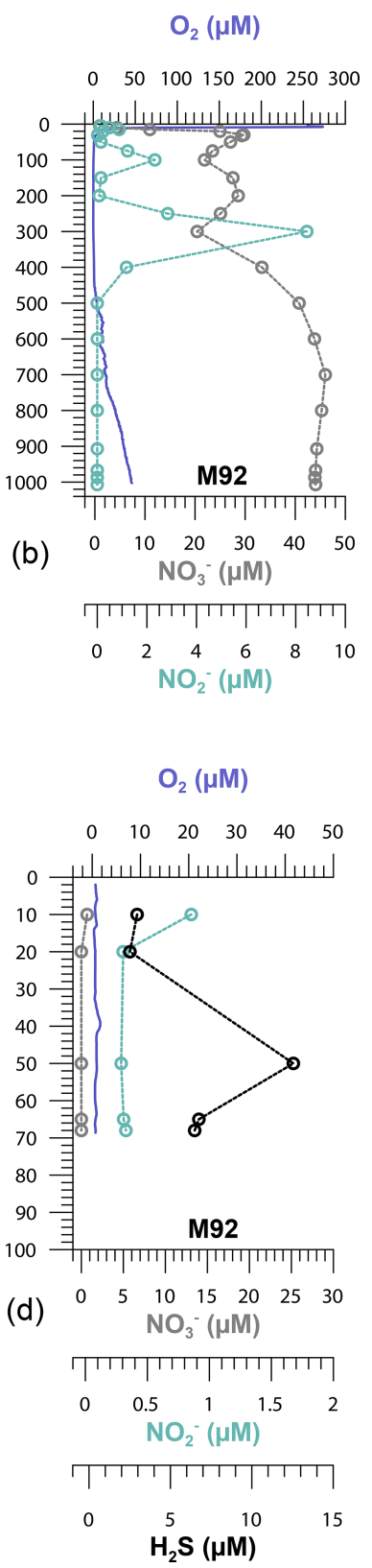

Figure 2. Oxygen $\left(\mathrm{O}_{2}\right)$, nitrate $\left(\mathrm{NO}_{3}^{-}\right)$, nitrite $\left(\mathrm{NO}_{2}^{-}\right)$and hydrogen sulfide $\left(\mathrm{H}_{2} \mathrm{~S}\right)$ concentrations on the Peruvian slope (Station 10, $1000 \mathrm{~m}$ depth), crossing the oxygen minimum zone (a, b), and the upper shelf (Station 1, $75 \mathrm{~m}$ depth) (c, d) during cruises M136M137 and M92 along the $12^{\circ} \mathrm{S}$ transect.

\section{Discussion}

\subsection{Benthic iron cycling}

\subsubsection{Comparison of diffusive and in situ benthic chamber iron fluxes}

Concentrations of $\mathrm{Fe}$ in bottom waters from benthic chamber incubations are mostly higher than in ambient bottom waters
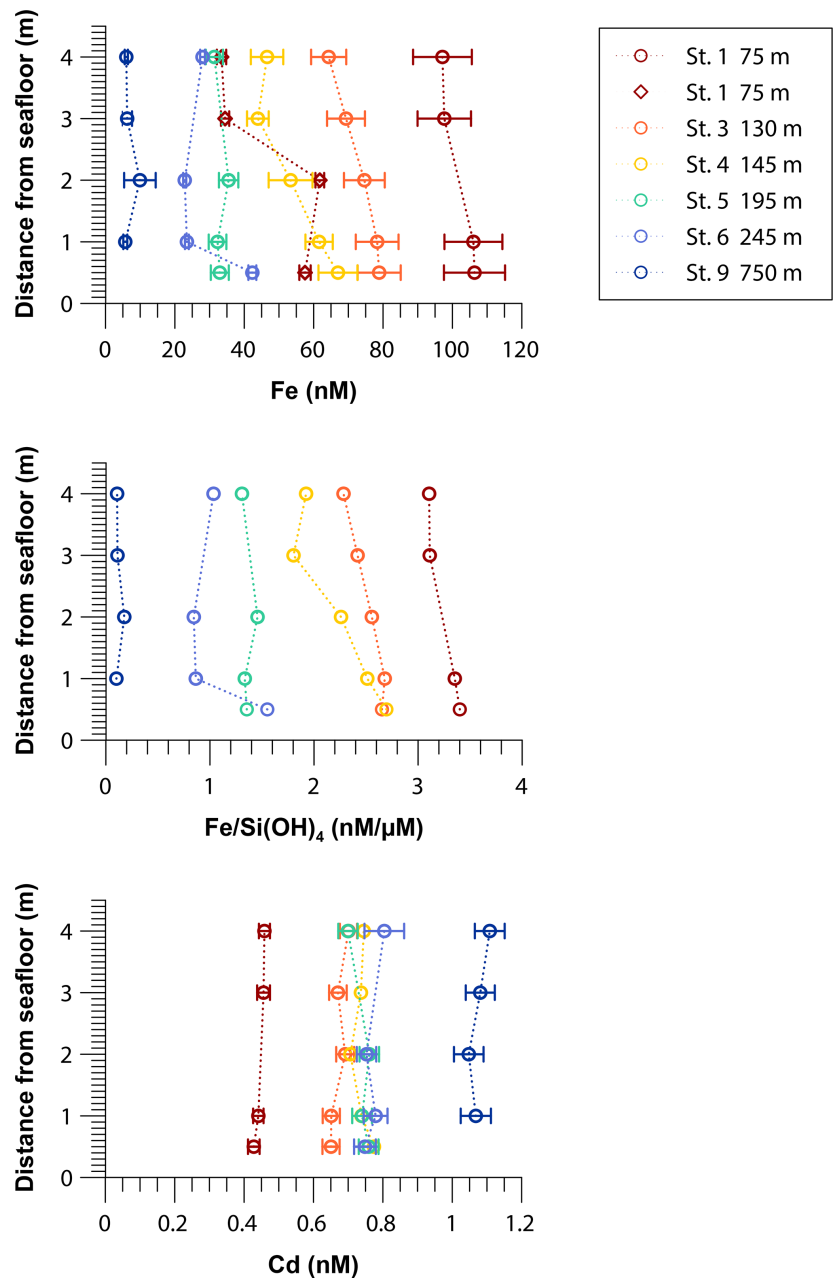

Figure 3. Near-bottom water concentrations of dissolved $\mathrm{Fe}$ and $\mathrm{Cd}$ and dissolved $\mathrm{Fe}$ to silicic acid ratios 0.5 to $4 \mathrm{~m}$ above the seafloor across the $12^{\circ} \mathrm{S}$ transect. The red diamonds show results from a second sampling at Station 1 one month later. Concentrations of silicic acid are listed in Table S3.

due to Fe release from the sediment and an accumulation in the enclosed water volume inside the benthic chamber. In the absence of oxygen and, thus, bottom-dwelling macrofauna at stations within the OMZ, bioturbation and bioirrigation are unlikely to exert an important control on sedimentary Fe release. Consistent with this notion, the slope calculated from benthic diffusive fluxes is in good agreement with the concentration gradients observed within the benthic chambers at two stations within the OMZ (stations 4 and 6; Fig. 5). Moreover, our fluxes from benthic chamber incubations and diffusive fluxes are of a similar magnitude at these stations (Table 2). Therefore, diffusive transport of dissolved Fe from the sediment into the bottom water seems to be the main control on the concentration evolution observed within the benthic chamber.

Some of the concentration gradients in benthic chambers are nonlinear, indicating that the Fe flux was not constant 


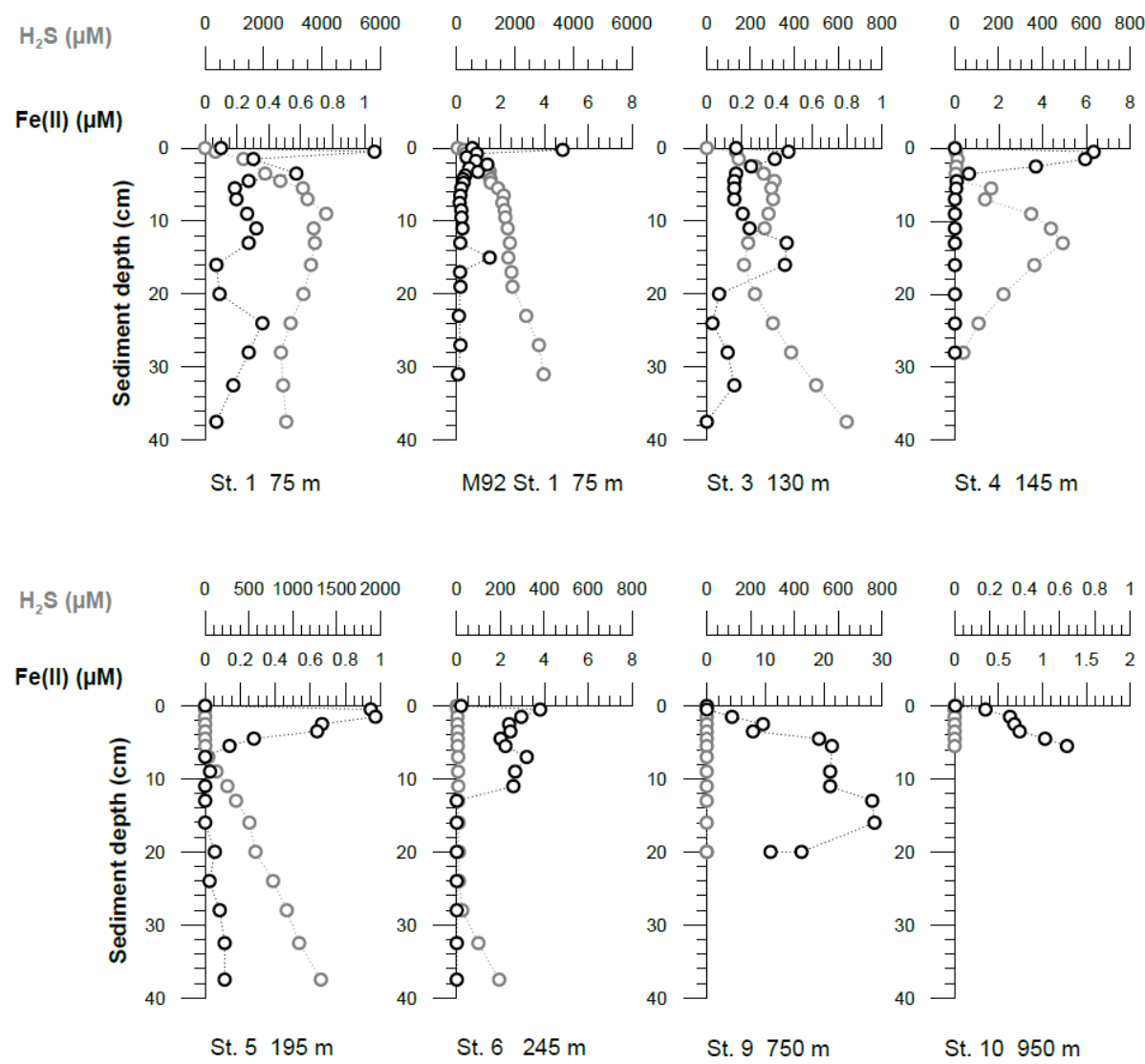

Figure 4. Pore water dissolved Fe(II) and hydrogen sulfide concentrations. Data from an earlier cruise, M92, at Station 1 (75 m water depth) are displayed for comparison. The uppermost sample represents the bottom water concentration. The analytical error is smaller than the symbol size.

during the incubations. This is a common observation in $\mathrm{Fe}$ flux data from benthic chamber incubations, and higher $\mathrm{Fe}$ fluxes generally have higher $R^{2}$ values for the linear regressions (Friedrich et al., 2002; Turetta et al., 2005; Severmann et al., 2010; Lenstra et al., 2019). However, the nonlinearity can be used to identify additional processes affecting Fe concentrations and fluxes within the benthic chamber, which may also affect fluxes under natural conditions. One possible process that can remove dissolved $\mathrm{Fe}(\mathrm{II})$ under anoxic conditions is $\mathrm{Fe}$ oxidation with $\mathrm{NO}_{3}^{-}$as the terminal electron acceptor or oxidation with $\mathrm{NO}_{2}^{-}$(Straub et al., 1996; Carlson et al., 2013; Klueglein and Kappler, 2013). The oxidation of reduced $\mathrm{Fe}$ in the absence of oxygen, either microbially mediated with $\mathrm{NO}_{3}^{-}$or abiotically with $\mathrm{NO}_{2}^{-}$, has been hypothesized to be important in the water column of the Peruvian OMZ (Scholz et al., 2016; Heller et al., 2017). During our incubation at Station 4 (Fig. 8), we observed a decline in $\mathrm{Fe}$ concentrations during the first $10 \mathrm{~h}$ of the incubation period. Concurrently, $\mathrm{NO}_{3}^{-}$concentrations were decreasing, while $\mathrm{NO}_{2}^{-}$accumulated, presumably due to progressive denitrification and release from the sediments. Once $\mathrm{NO}_{3}^{-}$and $\mathrm{NO}_{2}^{-}$were depleted, Fe concentrations started to rise again, resulting in the highest in situ $\mathrm{Fe}$ flux observed during our sampling campaign (Table 2). The coincidence in the timing of $\mathrm{Fe}$ accumulation and $\mathrm{NO}_{2}^{-}$decrease suggest that the depletion of $\mathrm{Fe}$ at the beginning of the incubation was most likely caused by $\mathrm{Fe}$ oxidation with $\mathrm{NO}_{2}^{-}$. The incubation at Station 4 was the only situation where $\mathrm{NO}_{3}^{-}$and $\mathrm{NO}_{2}^{-}$were substantially removed during the incubation. However, the high Fe flux cannot be interpreted as a natural flux estimate at steady state. In general, we argue that bottom water $\mathrm{NO}_{2}^{-}$ concentrations exert a first-order control on the intensity of Fe efflux in the absence of oxygen and, therefore, need to be considered in the evaluation of sedimentary Fe mobility in anoxic-nitrogenous OMZs.

During the incubations at stations 1,9 and 10 , Fe concentrations did not continuously increase but fluctuated between high and low values. This observation could be explained by a combination of bioirrigation and bioturbation at stations where oxygen was present (stations 9 and 10), as well as rapid $\mathrm{Fe}$ oxidation and precipitation processes. Under oxic conditions, bottom-dwelling macrofauna is likely to increase the transfer of dissolved Fe from the sediments into the bottom water (Elrod et al., 2004; Lenstra et al., 2019). During episodes of oxygenation, a population of macrofauna that can enhance bioturbation and bioirrigation was observed on the 

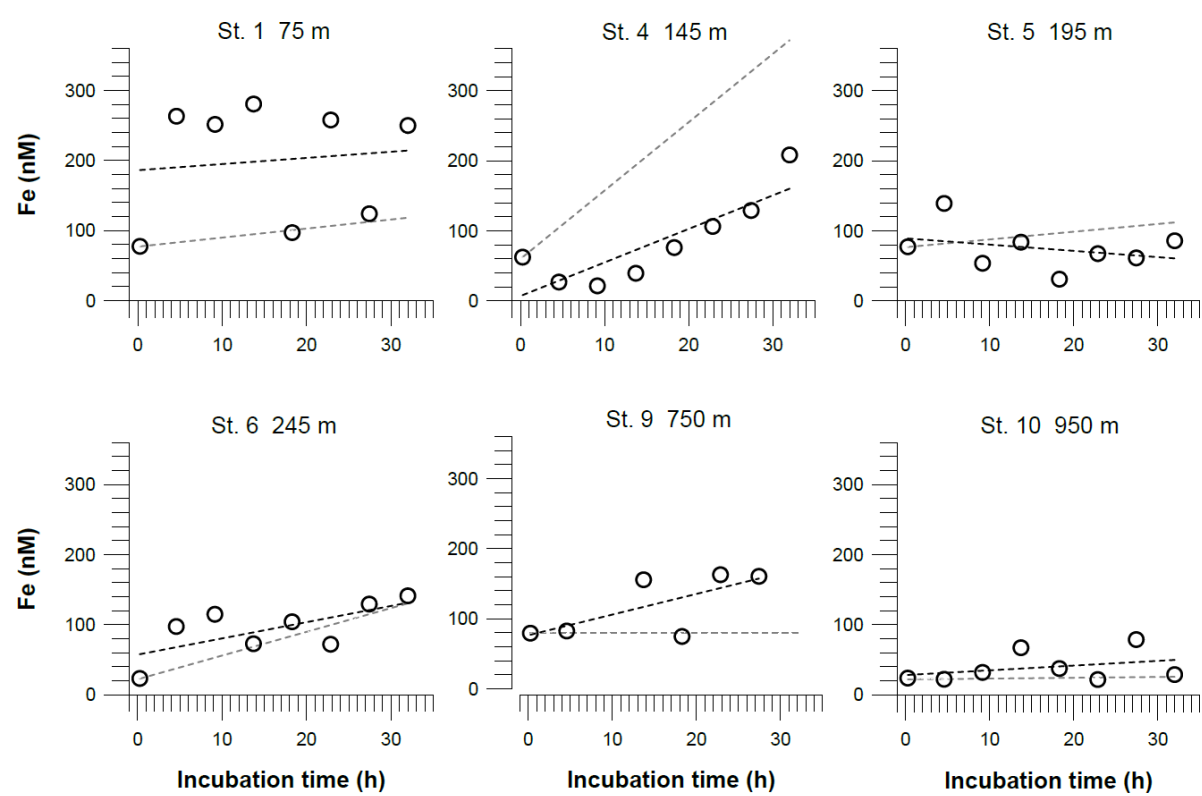

Figure 5. Dissolved Fe concentrations in incubated bottom waters from benthic chamber incubations. The black dashed line represents the linear regressions of the concentration change over the incubation time. The equations for these linear regressions are listed along with the coefficients of determination $\left(R^{2}\right)$ in Table S4. The gray dashed line represents theoretical concentration gradients over the incubation time based on our benthic diffusive fluxes (Table 2). The analytical error is smaller than the symbol size.

Peruvian shelf (Gutiérrez et al., 2008). However, under oxic conditions, any $\mathrm{Fe}$ delivered to the chamber is prone to rapid oxidative removal. Moreover, results from ex situ sediment incubations have demonstrated a fast and efficient removal of up to $90 \%$ of dissolved $\mathrm{Fe}$ in incubated bottom waters due to particle resuspension (Homoky et al., 2012). Bioturbation and bioirrigation could also contribute to particle resuspension at oxic stations, thereby leading to the removal of dissolved Fe.

Furthermore, colloidal Fe could modify Fe concentrations within our samples and explain some of the fluctuations observed during the incubations. Colloids are quite reactive and much more soluble than larger particles. Therefore, they can be rapidly reduced and dissolved in anoxic environments, but they can also aggregate into larger particles (Raiswell and Canfield, 2012). The transfer of Fe between dissolved, colloidal and particulate pools is likely to affect the balance between $\mathrm{Fe}$ transport and reprecipitation and redeposition to some extent. However, as we did not differentiate between colloidal and truly dissolved fractions during our sampling, we cannot discuss this aspect further based on our data.

Oxidation processes and interactions with particles can efficiently remove $\mathrm{Fe}$ shortly after its transfer to bottom waters, and this process is likely to be most intense close to the seafloor where the highest particle concentrations prevail. We argue that the same processes are reflected by declining $\mathrm{Fe}$ concentrations away from the seafloor in some of the bottom water profiles (stations 3 and 4; Fig. 3).

\subsubsection{Removal rates of dissolved iron in the near-bottom water column}

We observed declining Fe concentrations in the first $4 \mathrm{~m}$ from the seafloor at stations 3 and 4 , which hints at the removal of dissolved $\mathrm{Fe}$ in the near-bottom waters after its release from the sediments. To differentiate between dilution with ambient bottom water (by currents) and Fe removal from the dissolved phase, $\mathrm{Fe}$ concentrations were normalized by $\mathrm{Si}(\mathrm{OH})_{4}$ measured in the same samples (Fig. 3). Due to opal dissolution within sediments on the Peruvian shelf, $\mathrm{Si}(\mathrm{OH})_{4}$ is released into bottom waters (Ehlert et al., 2016). In contrast to $\mathrm{Fe}$, we assume that $\mathrm{Si}(\mathrm{OH})_{4}$ behaves conservatively and that precipitation reactions within the bottom waters are of subordinate importance. The decreasing $\mathrm{Fe}$ to $\mathrm{Si}(\mathrm{OH})_{4}$ ratios at stations 3 and 4 with distance from the seafloor indicate that there is Fe removal within the near-bottom water column that must be related to precipitation processes or scavenging.

We further constrained rates of dissolved Fe removal at stations with a discernable $\mathrm{Fe}$ to $\mathrm{Si}(\mathrm{OH})_{4}$ gradient within the first $4 \mathrm{~m}$ from the seafloor. To this end, we first determined an eddy diffusion coefficient $\left(K_{y}\right)$ using $\mathrm{Si}(\mathrm{OH})_{4}$ fluxes from benthic chamber incubations $\left(F_{\mathrm{Si}}\right.$; see Sect. 2.3 for methodology) and the known concentration gradient of dissolved $\mathrm{Si}(\mathrm{OH})_{4}$ within the bottom water $\left(\mathrm{d}_{\mathrm{Si}} / \mathrm{d}_{x}\right)$, where $x$ is the height above the seafloor. At the seafloor, the flux of $\mathrm{Si}(\mathrm{OH})_{4}$ from the sediment is equal to the flux in the water column.

$F_{\mathrm{Si}}=-K_{y}\left(\mathrm{~d}_{\mathrm{Si}} / \mathrm{d}_{x}\right)$ 


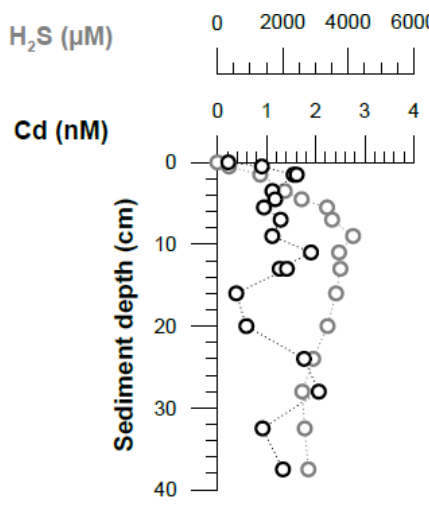

St. $175 \mathrm{~m}$
$0 \quad 200 \quad 400 \quad 600 \quad 800$

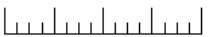

$\begin{array}{lllll}0 & 1 & 2 & 3 & 4\end{array}$

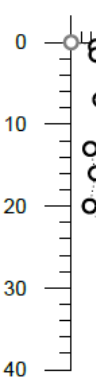

-

St. $3130 \mathrm{~m}$

(o)

00

0
$0 \quad 200400600800$

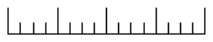

$\begin{array}{lllll}0 & 1 & 2 & 3 & 4\end{array}$
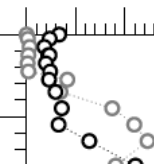

o

$\infty$

- o

40

St. $4145 \mathrm{~m}$

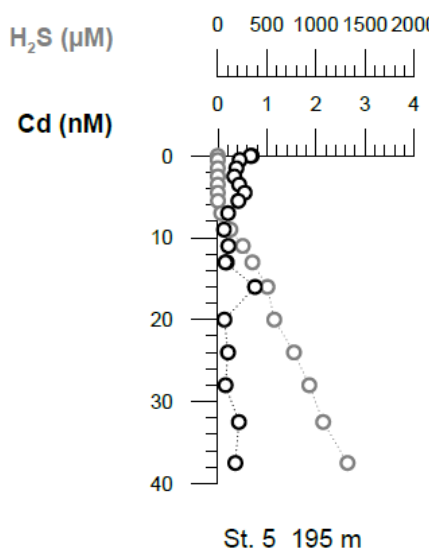

$0 \quad 200 \quad 400600800$

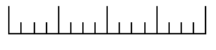

$0 \quad 200400600800$
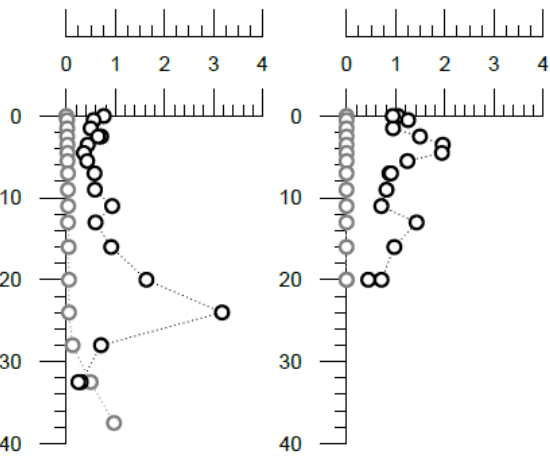

St. $9750 \mathrm{~m}$

Figure 6. Pore water dissolved $\mathrm{Cd}$ and $\mathrm{H}_{2} \mathrm{~S}$ concentrations. The uppermost sample represents the bottom water concentrations. The analytical error is smaller than the symbol size.

This equation can be solved for the eddy diffusion coefficient.

Dissolved $\mathrm{Fe}$ in the bottom water (DFe) can be described by the solving the diffusion-reaction equation for DFe (ignoring advection and assuming a steady-state first-order consumption of dissolved $\mathrm{Fe}$ ):

$\mathrm{DFe}=C_{\mathrm{BW}} \times \exp \cdot\left(-\sqrt{k_{\mathrm{Feox}}} / \sqrt{K_{y}}\right)$

The equation can be fitted to the measured DFe concentrations in the bottom water by adjusting the $\mathrm{Fe}$ concentration directly above the seafloor $\left(C_{\mathrm{BW}}\right)$ and the $\mathrm{Fe}$ oxidation constant $\left(k_{\mathrm{Feox}}\right)$. From the fitted first-order rate constant $k_{\mathrm{Feox}}$, the half-life for dissolved Fe in bottom waters can be calculated.

The half-lives of dissolved $\mathrm{Fe}$ in the first $4 \mathrm{~m}$ from the seafloor are 2.5 and $0.3 \mathrm{~min}$ at stations 3 and 4 , respectively (Table 4). Another study reported a dissolved Fe half-life of $17 \mathrm{~h}$ under nitrogenous conditions in the first $10-20 \mathrm{~m}$ above the seafloor in the Peruvian OMZ (Scholz et al., 2016). Our calculations suggest that Fe removal in near-bottom waters is much faster. The approach assumes that $\mathrm{Si}(\mathrm{OH})_{4}$ is trans- ported vertically by eddy diffusion and that oxidation controls the half-life of $\mathrm{Fe}$ in the first $4 \mathrm{~m}$ above the seafloor. It is possible that our assumption of solute transport by eddy diffusion is not correct. Alternatively, decreasing $\mathrm{Fe}$ and $\mathrm{Si}(\mathrm{OH})_{4}$ concentration above the seafloor could be due to superimposed water layers with different $\mathrm{Fe}$ and $\mathrm{Si}(\mathrm{OH})_{4}$ concentrations but little vertical exchange. In this case our calculated half-life would be an underestimation.

As mentioned above (Sect. 4.1.1), in the absence of oxygen, removal processes of dissolved Fe could be related to the oxidation of dissolved $\mathrm{Fe}$ with $\mathrm{NO}_{2}^{-}$or to interactions with suspended particles, which are likely to be most abundant directly above the seafloor. Further research on dissolvedparticulate interactions, including the role of colloidal $\mathrm{Fe}$, in bottom waters is needed to better constrain how sedimentary Fe fluxes are modified in the near-bottom water column.

\subsubsection{Controls on the temporal variability of benthic iron fluxes}

The Peruvian OMZ is known to experience high-amplitude fluctuations in upwelling intensity as well as variability in 

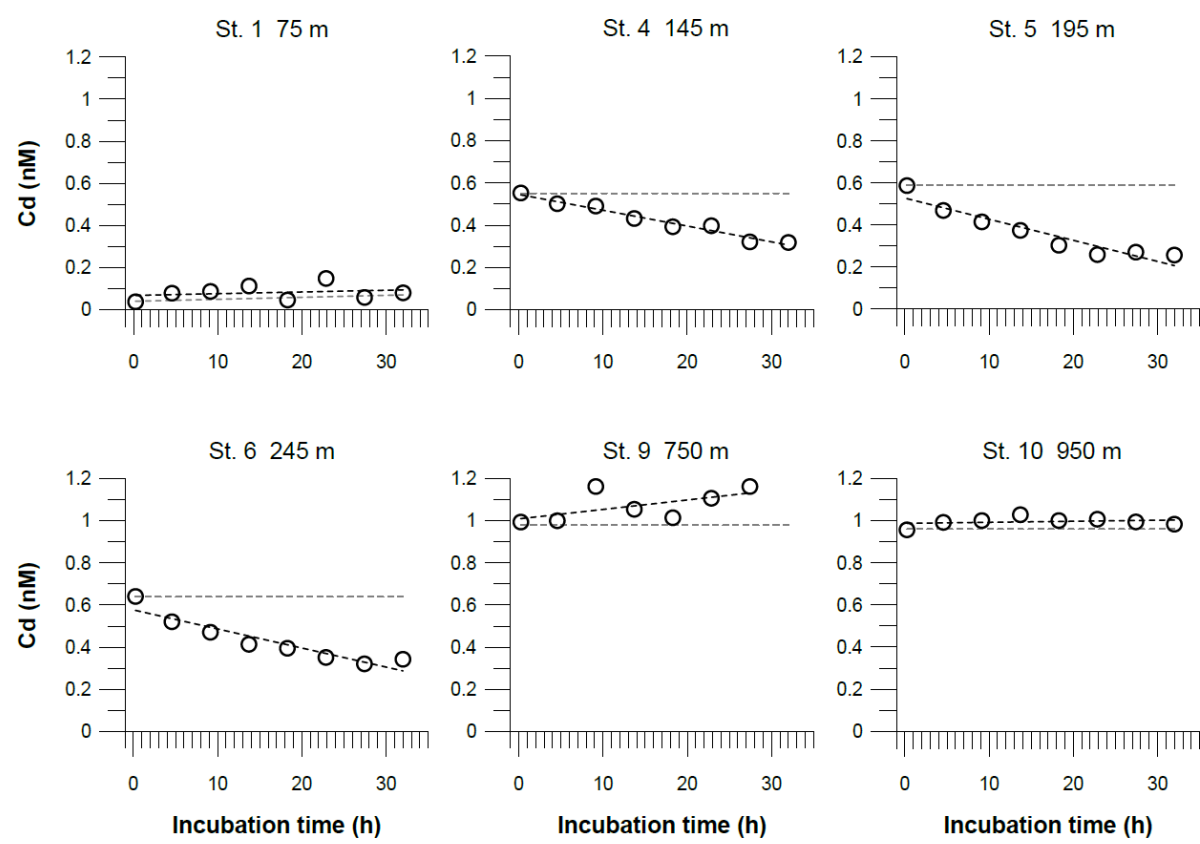

Figure 7. Dissolved Cd concentrations in incubated bottom waters from benthic chamber incubations. The black dashed line represents the linear regressions of the concentration change over the incubation time. The equations for these linear regressions are listed along with the coefficients of determination $\left(R^{2}\right)$ in Table $\mathrm{S} 4$. The gray dashed line represents the theoretical concentration gradients over the incubation time based on our benthic diffusive fluxes (Table 3). The analytical error is smaller than the symbol size.

Table 4. Modeled half-lives $\left(t_{1 / 2}\right)$ of dissolved Fe within the first $4 \mathrm{~m}$ from the seafloor at stations 3 and 4 , and data used for determination of $t_{1 / 2}$ using Eqs. (4) and (5).

\begin{tabular}{lcrrrrrr}
\hline Station & $\begin{array}{r}\text { Water } \\
\text { depth }\end{array}$ & $\begin{array}{r}\mathrm{Si}(\mathrm{OH})_{4} \text { flux } \\
\text { benthic } \\
\text { chamber }\left(F_{\mathrm{Si}}\right)\end{array}$ & $\begin{array}{r}\mathrm{Si}(\mathrm{OH})_{4} \\
\text { concentration } \\
\text { gradient }\left(\mathrm{d}_{\mathrm{Si}}\right)\end{array}$ & $\begin{array}{r}\text { Eddy diffusion } \\
\text { coefficient } \\
\left(K_{\mathrm{y}}\right)\end{array}$ & $\begin{array}{r}\text { Modeled Fe at } \\
\text { sediment } \\
\text { surface }\left(C_{\mathrm{BW}}\right)\end{array}$ & $\begin{array}{r}\text { Fe oxidation } \\
\text { constant } \\
\left(k_{\mathrm{Feox}}\right)\end{array}$ & $\begin{array}{r}\text { Half-life in near- } \\
\text { bottom water } \\
\text { column }\left(t_{1 / 2}\right)\end{array}$ \\
\cline { 2 - 8 } & $(\mathrm{m})$ & $\left(\mu \mathrm{mol} \mathrm{cm}{ }^{-2} \mathrm{~d}^{-1}\right)$ & $\left(\mu \mathrm{mol} \mathrm{cm}{ }^{-3} \mathrm{~cm}^{-1}\right)$ & $\left(\mathrm{m}^{2} \mathrm{~s}^{-1}\right)$ & $(\mathrm{nM})$ & $(\mathrm{m})$ & $\left(\mathrm{d}^{-1}\right)$ \\
\hline 3 & 130 & 0.73 & $-4.05 \times 10^{-6}$ & $1.55 \times 10^{6}$ & 70 & 400 & 2.5 \\
4 & 145 & 0.33 & $-1.44 \times 10^{-6}$ & $1.96 \times 10^{6}$ & 81 & 3500 & 0.3 \\
\hline
\end{tabular}

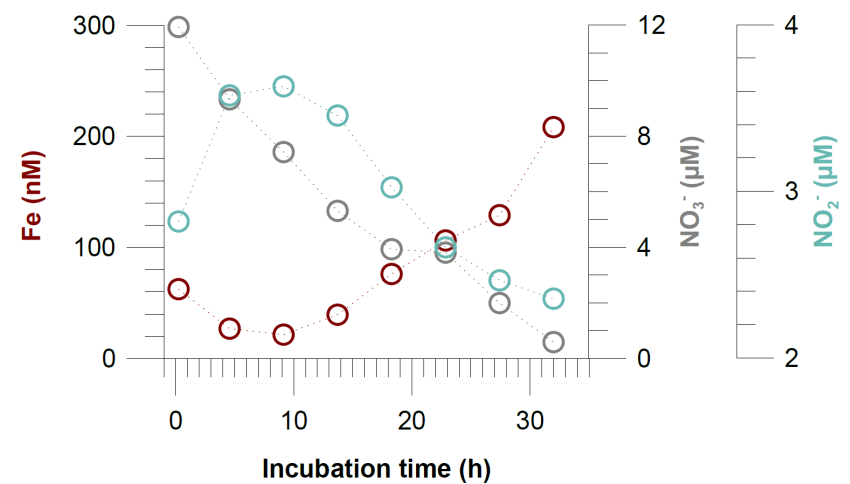

Figure 8. Dissolved Fe, nitrate $\left(\mathrm{NO}_{3}^{-}\right)$and nitrite $\left(\mathrm{NO}_{2}^{-}\right)$concentrations in incubated bottom waters from the benthic chamber incubation at Station 4 (145 m water depth). bottom water oxygen, $\mathrm{NO}_{3}^{-}, \mathrm{NO}_{2}^{-}$and $\mathrm{H}_{2} \mathrm{~S}$ concentrations (Pennington et al., 2006; Gutiérrez et al., 2008; Graco et al., 2017; Ohde, 2018). To get an insight into how different biogeochemical conditions control benthic diffusive Fe(II) fluxes, we compared the fluxes from our recent cruise with fluxes from our earlier cruise M92 (Fig. 9). Cruise M92 took place in austral autumn 2013 following the main upwelling season and during a period of intense primary productivity. Due to reduced upwelling and stable density stratification, the water column on the shallow shelf was not only depleted in oxygen but also in $\mathrm{NO}_{3}^{-}$and $\mathrm{NO}_{2}^{-}$during cruise M92 (Sommer et al., 2016). Under such conditions, chemolithoautotrophic $\mathrm{H}_{2} \mathrm{~S}$ oxidation with $\mathrm{NO}_{3}^{-}$or $\mathrm{NO}_{2}^{-}$was impeded so that pore water $\mathrm{H}_{2} \mathrm{~S}$ could be released from the sediment into the water column. As a result, the water column during M92 was sulfidic between water depths from around 50 to $150 \mathrm{~m}$ with the highest $\mathrm{H}_{2} \mathrm{~S}$ concentration of $13 \mu \mathrm{M}$ observed at 


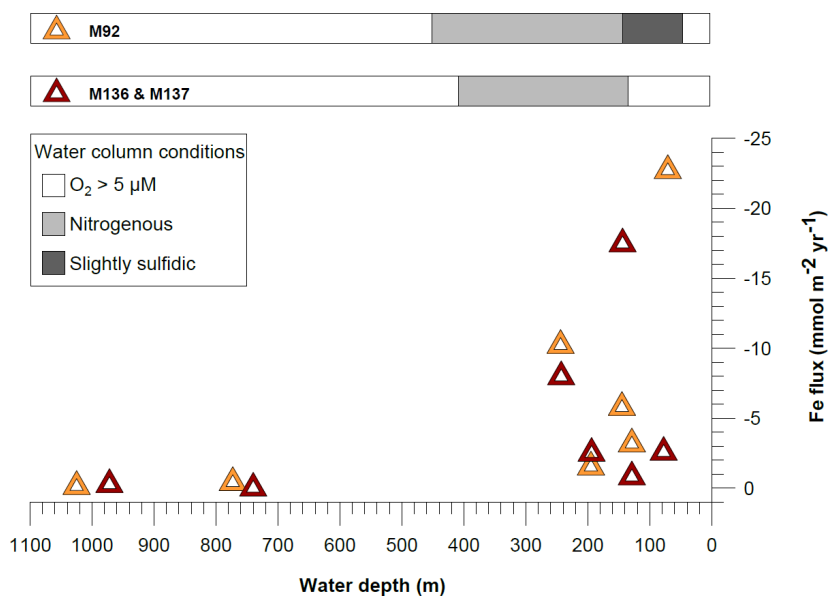

Figure 9. Comparison of benthic diffusive Fe(II) fluxes between cruises M136-M137 and M92 (data from Schroller-Lomnitz et al., 2019) on the Peruvian shelf. Negative values represent fluxes from the sediment pore water into the bottom waters. The shaded bars above the panel display the geochemical conditions in the water column during the time of sampling.

a depth of $50 \mathrm{~m}$ (Fig. 2). While the biogeochemical conditions on the shallow shelf were fundamentally different from those during M136 and M137, below a water depth of $150 \mathrm{~m}$ the conditions were largely comparable (oxygen-depleted; $\mathrm{NO}_{3}^{-}$of $20-0 \mu \mathrm{M}$ and $\mathrm{NO}_{2}^{-}$up to $9 \mu \mathrm{M}$ between 150 and $300 \mathrm{~m})$. At the stations with similar biogeochemical water column conditions, the Fe(II) fluxes during both sampling campaigns were remarkably similar (Fig. 9). However, similar to the temporal variability of Fe concentrations in bottom waters at Station 1 (Fig. 3), we observed a pronounced difference in the diffusive flux magnitude on the shallow shelf where the biogeochemical conditions differed between both cruises. The highest diffusive flux during M92 in 2013 of $-22.7 \mathrm{mmol} \mathrm{m}^{-2} \mathrm{yr}^{-1}$ was measured at Station 1 . By contrast, during M136 and M137 in 2017 we determined a much lower flux of $-2.6 \mathrm{mmol} \mathrm{m}^{-2} \mathrm{yr}^{-1}$ at this station. During M136 and M137 the highest flux of $-17.5 \mathrm{mmol} \mathrm{m}^{-2} \mathrm{yr}^{-1}$ was measured at Station 4 at a water depth of $145 \mathrm{~m}$.

Diffusive fluxes are a function of the concentration gradient between pore water and bottom water (Eq. 1). As dissolved $\mathrm{Fe}$ concentrations in bottom waters are generally much lower (nanomoles) than those observed in pore waters (micromoles), the flux magnitude is chiefly determined by differences in pore water Fe concentrations. During M92, pore waters at the sediment surface were characterized by high dissolved Fe concentrations $(4.8 \mu \mathrm{M}$ in the upper pore water sample), which resulted in a steep gradient and a comparably high Fe flux. Under the slightly sulfidic conditions that prevailed in the water column during M92, the oxidative removal of dissolved $\mathrm{Fe}(\mathrm{II})$ with $\mathrm{NO}_{3}^{-}$or $\mathrm{NO}_{2}^{-}$was impeded (Scholz et al., 2016) and dissolved Fe(II) could be stabilized as aqueous iron sulfide (Schlosser et al., 2018). Therefore, the bottom water was characterized by high dissolved Fe concentrations (up to $0.7 \mu \mathrm{M}$ in the supernatant bottom water of MUCs).

Despite oxic conditions in the water column during M136 and M137, we observed much higher $\mathrm{H}_{2} \mathrm{~S}$ concentrations in surface sediments at Station 1 compared with M92 $(4100 \mu \mathrm{M}$ during M136 and M137 versus $1800 \mu \mathrm{M}$ during M92 within the first $8 \mathrm{~cm}$ of the core; Fig. 4). Because of higher $\mathrm{H}_{2} \mathrm{~S}$ concentrations, Fe concentrations were controlled by the solubility of Fe monosulfide minerals (FeS). It may seem counterintuitive that the surface sediment was highly sulfidic while the overlying water column was oxygenated. In order to explain this observation, we need to consider the role of mats of filamentous sulfur-oxidizing bacteria in controlling $\mathrm{H}_{2} \mathrm{~S}$ concentrations in surface sediments. (Gutiérrez et al., 2008; Noffke et al., 2012; Yücel et al., 2017). During M92 these mats were generally abundant on the shelf and upper slope (Sommer et al., 2016), thereby limiting the extent of $\mathrm{H}_{2} \mathrm{~S}$ accumulation within surface sediments. Previous studies have demonstrated that mats of sulfur-oxidizing bacteria can disappear during periods of oxygenation (Gutiérrez et al., 2008). Consistent with this previous observation, visual inspection of the seafloor using the video-guided MUC revealed that the abundance of bacterial mats on the seafloor seemed greatly reduced, which was most probably related to oxic bottom water conditions on the shallow shelf during the coastal El Niño event. As these microaerophilic organisms tend to avoid high oxygen concentrations they probably started to die off or withdraw into the sediment once oxygen levels increased. We suggest that the disappearance of sulfide-oxidizing bacteria under oxic conditions created a situation where $\mathrm{H}_{2} \mathrm{~S}$ accumulation in the surface sediment and FeS precipitation limited the extent of $\mathrm{Fe}$ release into the bottom water.

\subsection{Benthic cadmium cycling}

\subsubsection{Comparison of diffusive and in situ benthic chamber cadmium fluxes}

At stations above and below the permanent OMZ (stations 1, 9 and 10), the slopes of Cd concentrations versus time during benthic chamber incubations were largely consistent with theoretical $\mathrm{Cd}$ concentration gradients over time based on our diffusive flux estimates (Fig. 7). In contrast, the fluxes determined with benthic chambers at stations within the $\mathrm{OMZ}$ (stations 4, 5 and 6) were 25 to 40 times higher than the diffusive flux (Table 3). This discrepancy demonstrates that diffusion cannot be the dominant process leading to the continuous decrease of dissolved $\mathrm{Cd}$ during benthic chamber incubations. Alternatively, Cd could be precipitated within the benthic chamber and removed through the downward sinking of Cd-rich particles. Cadmium sulfide (greenockite) has a relatively low solubility compared with sulfide minerals of other TMs $(\mathrm{CdS} \ll \mathrm{FeS})$. It is generally agreed that CdS precipitation can take place at trace amounts of $\mathrm{H}_{2} \mathrm{~S}\left(\mathrm{H}_{2} \mathrm{~S}<1 \mu \mathrm{M}\right.$, 
i.e., below the detection limit of the method applied in this study; Davies-Colley et al., 1985; Rosenthal et al., 1995). Previous studies using benthic chambers have concluded that the production of $\mathrm{H}_{2} \mathrm{~S}$ in the sediment or the accumulation of $\mathrm{H}_{2} \mathrm{~S}$ in benthic chambers during incubations can switch the direction of the Cd flux or intensify Cd removal through $\mathrm{CdS}$ precipitation (Westerlund et al., 1986; Colbert et al., 2001). Therefore, precipitation of CdS during the incubation is a viable explanation for the discrepancy between the diffusive $\mathrm{Cd}$ flux and Cd fluxes in benthic chambers observed in our study. Furthermore, the three different trends in the Cd concentrations observed in benthic chamber incubations can be related to $\mathrm{H}_{2} \mathrm{~S}$ concentrations in the surface sediment below the benthic chambers (Table 3). At stations within the OMZ (stations 4,5 and 6), pore water $\mathrm{H}_{2} \mathrm{~S}$ concentrations in surface sediments were moderate (a few micromoles). It is likely that there was a continuous leakage of trace amounts of $\mathrm{H}_{2} \mathrm{~S}$ from the pore water into the bottom waters during the incubation, leading to $\mathrm{CdS}$ precipitation and declining $\mathrm{Cd}$ concentrations. On the shallowest shelf station (Station 1), where pore water $\mathrm{H}_{2} \mathrm{~S}$ concentrations in the surface sediment were high (hundreds of micromoles), a potentially large amount could have been released at the beginning of the incubation, thereby explaining pronounced $\mathrm{Cd}$ depletion in the chamber compared with the surrounding bottom water $(0.1 \mathrm{nM}$ within the chamber compared with $0.4 \mathrm{nM}$ outside of the chamber). Below the OMZ (stations 9 and 10), where there was no $\mathrm{H}_{2} \mathrm{~S}$ present in surface sediments, there was no $\mathrm{Cd}$ depletion in the chamber during the incubation and, consistent with previous studies in oxic settings (Westerlund et al., 1986; Ciceri et al., 1992; Zago et al., 2000; Turetta et al., 2005), both diffusive and benthic chamber flux data were indicative of an upwarddirected flux out of the sediment. Due to the absence of $\mathrm{H}_{2} \mathrm{~S}$, dissolved $\mathrm{Cd}$ released from biogenic particles in the surface sediment could accumulate in the pore water and, thus, drive a diffusive flux out of the sediment.

\subsubsection{Quantification of the sedimentary cadmium sink}

Consistent with our Cd flux data, there is a general consensus that OMZs are a sink for Cd. Several water column studies have observed $\mathrm{Cd}$ depletion in water masses within the Peruvian and other OMZs, which was mostly attributed to $\mathrm{Cd}$ removal via CdS precipitation in sulfidic micro-niches within particles in the water column (Janssen et al., 2014; Conway and John, 2015b). Sedimentary studies showed that $\mathrm{Cd}$ is highly enriched in OMZ sediments, which has mostly been attributed to the delivery of $\mathrm{Cd}$ with organic material and subsequent fixation as CdS within sulfidic sediments (Ragueneau et al., 2000; Böning et al., 2004; Borchers et al., 2005; Muñoz et al., 2012; Little et al., 2015). Based on our data, we can quantify the delivery of $\mathrm{Cd}$ to the sediments via three different pathways: (1) diffusion across the sediment-water interface and CdS precipitation within the sediment; (2) Cd incorporation by phytoplankton and delivery to the sediment with organic matter; (3) CdS precipitation in the water column and particulate delivery to the sediment (Table 3).

The enrichment of $\mathrm{Cd}$ in the sediment relative to the lithogenic background (expressed as excess $\mathrm{Cd}$ concentration; $\left.\mathrm{Cd}_{\mathrm{xs}}\right)$ was calculated using the following equation (Brumsack, 2006):

$\mathrm{Cd}_{\mathrm{xs}}=\mathrm{Cd}_{\text {sample }}-\mathrm{Al}_{\text {sample }} \times(\mathrm{Cd} / \mathrm{Al})_{\text {crust }}$

The Cd/Al ratio of the upper continental crust $\left(1.22 \times 10^{-6}\right)$ was used as lithogenic background reference (Taylor and McLennan, 2009). To calculate the flux of $\mathrm{Cd}$ to the sediment, $\mathrm{Cd}_{\mathrm{xs}}$ was multiplied by the mass accumulation rate (MAR) from published data for each individual site (Dale et al., 2015b). To approximate the amount of $\mathrm{Cd}$ delivered to the sediment with organic material, the average concentration ratio of $\mathrm{Cd}$ to $\mathrm{C}$ in phytoplankton (Moore et al., 2013) was multiplied by published particulate organic carbon rain rates (maximum estimate) or burial rates (minimum estimate) for each individual site (Dale et al., 2015b). The Cd delivery via precipitation in the water column was determined as the remainder of $\mathrm{Cd}_{\mathrm{xs}} \times \mathrm{MAR}$ after the subtraction of the two other sources (i.e., diffusive flux and minimum/maximum delivery by organic material).

Sediments at all stations on the Peruvian shelf and slope are enriched in $\mathrm{Cd}$ relative to the lithogenic background. The accumulation rate of $\mathrm{Cd}$ decreases with distance from the coast from $250 \mu \mathrm{mol} \mathrm{m}{ }^{-2} \mathrm{yr}^{-1}$ at Station 1 to $4 \mu \mathrm{mol} \mathrm{m}^{-2} \mathrm{yr}^{-1}$ at Station 9 (Table 3). These fluxes generally exceed the amount of $\mathrm{Cd}$ delivered to the sediments via diffusion and associated with organic material. Together, these mechanisms of Cd delivery can only account for $20 \%$ of the Cd enrichment at stations above and inside the permanent OMZ, with the delivery with organic material being of greater importance. The remaining $\mathrm{Cd}$ enrichment in the sediment $(\sim 80 \%)$, after the subtraction of diffusive and minimum/maximum organic $\mathrm{Cd}$ sources, must be related to $\mathrm{CdS}$ precipitation in the water column and the delivery of $\mathrm{Cd}-$ rich particles to the sediment. This removal process can be a combination of $\mathrm{CdS}$ precipitation in sulfidic micro-niches around sinking particles (Janssen et al., 2014; Bianchi et al., 2018), CdS precipitation in sulfide plumes (Xie et al., 2019) when sedimentary $\mathrm{H}_{2} \mathrm{~S}$ can spread throughout the water column (Schunck et al., 2013; Ohde, 2018) and precipitation of $\mathrm{CdS}$ in the near-bottom water (this study). Our estimated CdS precipitation in the water column within the $\mathrm{OMZ}$ agrees with the $\mathrm{Cd}$ fluxes determined from benthic chamber incubations, where dissolved Cd removal takes place in the 20$30 \mathrm{~cm}$ of overlying water above the seafloor. These Cd removal fluxes from benthic chambers alone are sufficient to account for $41 \%-68 \%$ of the estimated particulate $\mathrm{Cd}$ removal from the water column and $38 \%-60 \%$ of total $\mathrm{Cd}$ enrichment in the sediment within the OMZ (Table 3). Considering that $\mathrm{Cd}$ precipitation in the near-bottom water is unlikely to be restricted to the $20-30 \mathrm{~cm}$ above the seafloor, 
covered by our benthic chambers, the removal flux associated with this process is likely to be even higher. At Station 1 , where the surface sediment below the benthic chamber was highly sulfidic, the particulate $\mathrm{Cd}$ removal calculated from the concentration difference between the bottom water $(0.5 \mathrm{~m})$ and the first sample from the benthic chamber incubation (taken after $0.25 \mathrm{~h}$ ) was high enough to explain the total Cd enrichment in the sediment. Below the OMZ, at Station 9, where the smallest $\mathrm{Cd}$ enrichment was observed, the relative contribution of $\mathrm{Cd}$ delivery with organic material increases. About half of the $\mathrm{Cd}$ enrichment can be attributed to organic material at this station.

Once $\mathrm{Cd}$ is delivered to the sediment, it can either stay fixed in the solid phase or be released to the pore waters. Cadmium concentrations in pore waters of subsurface sediments $(>10 \mathrm{~cm}$ sediment depth) were mostly higher than bottom water concentrations (Fig. 6), indicating a transfer of $\mathrm{Cd}$ from the solid phase into pore waters during early diagenesis. Cadmium sulfides are considered highly insoluble and stable within sediments (Elderfield et al., 1981), even upon reoxygenation (Rosenthal et al., 1995). Therefore, Cd release through redissolution of $\mathrm{CdS}$ is ruled out as a potential source of dissolved Cd. Alternatively, Cd liberation upon remineralization of organic material could explain elevated Cd concentrations in the pore water. Elevated $\mathrm{Cd}$ concentrations in sulfidic pore waters have been observed in previous studies and have been attributed to $\mathrm{Cd}$ stabilization through formation of organic and inorganic complexes (Gobeil et al., 1987; Sundby et al., 2004). Experimental data gave evidence for the presence of dissolved $\mathrm{Cd}$ bisulfide and polysulfide complexes in pore waters. An increase in electrochemically active Cd after UV irradiation was explained by the destruction of electrochemically inactive bisulfide and polysulfide complexes (Gobeil et al., 1987). At very high $\mathrm{H}_{2} \mathrm{~S}$ concentrations $\left(>10^{-3} \mathrm{M}\right)$, the solubility of $\mathrm{Cd}$ may increase due to an increase in these bisulfide and polysulfide complexes. Under such highly sulfidic conditions, Cd solubility may even exceed the solubility in oxygenated waters and highly sulfidic sediment can eventually lead to a diffusive source of $\mathrm{Cd}$ to the bottom water (Davies-Colley et al., 1985). Such a scenario may explain the negative (i.e., upward-directed) diffusive Cd flux at Station 1, where the pore waters of surface sediments are highly sulfidic.

\section{Conclusions and implications for trace metal sources and sinks in the future ocean}

Consistent with earlier work, our results demonstrate that OMZ sediments are a source for $\mathrm{Fe}$ and a sink for Cd. Moreover, based on our findings, biogeochemical conditions and processes that control the benthic fluxes of these TMs across the Peruvian OMZ can be further constrained.

Within the OMZ, where bottom dwelling macrofauna is absent, diffusion is the main process that transports $\mathrm{Fe}$ from

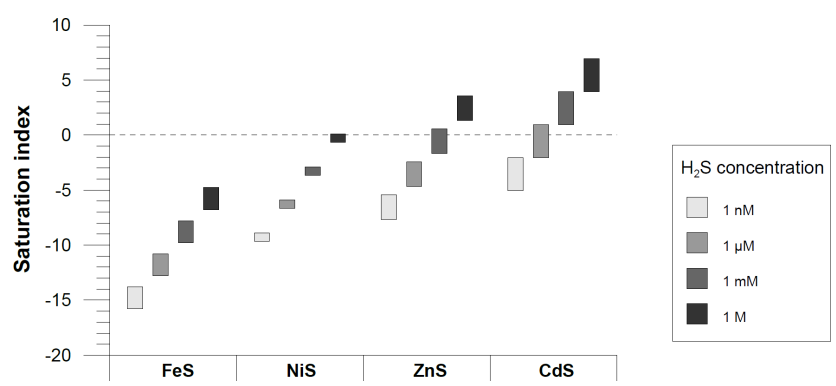

Figure 10. Schematic overview of the possible mobility of different trace metals to an expansion of sulfidic conditions. Saturation indices (SIs) were calculated for different $\mathrm{H}_{2} \mathrm{~S}$ concentrations and reported minimum and maximum concentrations of trace metals in the water column (data from Bruland and Lohan, 2003). Equilibrium constants (log $\mathrm{K}$ under standard conditions) for $\mathrm{Fe}$ ( $\mathrm{FeS}$ ppt: -3.92), Ni (millerite: -8.04), $\mathrm{Zn}$ (sphalerite: -11.62 ) and $\mathrm{Cd}$ (greenockite: -15.93 ) were taken from the PHREEQC WATEQ4F database (Ball and Nordstrom, 1991).The results are approximate as concentrations instead of activities were used for calculations. A positive SI is indicative of oversaturation, whereas a negative SI is indicative of undersaturation.

the sediment pore water into the bottom water. The accumulation of high levels of $\mathrm{H}_{2} \mathrm{~S}$ in pore waters, modulated by the abundance of sulfur-oxidizing bacteria, can reduce diffusive Fe release through sulfide precipitation within pore waters. In anoxic bottom waters, $\mathrm{Fe}$ can be rapidly removed, likely via oxidation with $\mathrm{NO}_{2}^{-}$and/or interaction with particles. Benthic $\mathrm{Cd}$ fluxes are directed from the bottom water into the sediment within the OMZ. Diffusive fluxes and the delivery of Cd via organic material cannot account for the sedimentary Cd enrichment. Instead CdS precipitation in near-bottom waters could be the most important pathway that delivers $\mathrm{Cd}$ to the sediments.

According to our results, $\mathrm{H}_{2} \mathrm{~S}$ concentrations in surface sediments exert a first-order control on the magnitude and direction of $\mathrm{Fe}$ and $\mathrm{Cd}$ fluxes across the sediment-water interface. With generally decreasing oxygen concentrations in the ocean and an expansion of OMZs (Stramma et al., 2008; Schmidtko et al., 2017), sulfidic surface sediments will likely also expand. With regard to the solubility of their sulfide minerals, $\mathrm{Fe}$ and $\mathrm{Cd}$ represent two opposite end-members. The solubility of sulfide minerals of other important nutrient-type $\mathrm{TMs}$, such as $\mathrm{Ni}$ and $\mathrm{Zn}$, is intermediate between those of $\mathrm{Fe}$ and $\mathrm{Cd}(\mathrm{Fe}>\mathrm{Ni}>\mathrm{Zn}>\mathrm{Cd})$. Thus, an expansion of sulfidic surface sediments is likely to affect sedimentary TM fluxes in a differing manner. This notion is illustrated in Fig. 10, which shows saturation indices calculated based on the range of TM concentrations observed in the ocean and typical $\mathrm{H}_{2} \mathrm{~S}$ concentrations observed in anoxic marine environments (nanomole to micromole concentrations represent sulfidic events in the water column; micromole to millimole concentrations are typical for pore waters). Cadmium sulfide minerals become oversaturated at nanomole to micro- 
mole $\mathrm{H}_{2} \mathrm{~S}$ concentrations, which explains why Cd removal can take place in the bottom water in OMZs. By contrast, $\mathrm{FeS}$ is highly undersaturated under the typical biogeochemical conditions in the water column. Therefore, FeS precipitation is unlikely to take place in the water column, even under somewhat more reducing conditions. Other sulfide-forming TMs have an intermediate sulfide solubility (e.g., $\mathrm{Zn}$ and $\mathrm{Ni}$ ), which could imply that the direction and magnitude of their sedimentary fluxes is susceptible to expanding ocean anoxia. The differing response of TMs to an expansion of sulfidic conditions may cause a change in the TM stoichiometry of upwelling water masses with potential consequences for TMdependent marine ecosystems in surface waters.

Data availability. The data acquired for this study are available at https://doi.org/10.1594/PANGAEA.918805 (Plass et al., 2020). The hydrochemical water column data are available at https://doi.org/10.1594/PANGAEA.862046 (Dengler, 2016), https://doi.org/10.1594/PANGAEA.904404 (Sommer and Dengler, 2019a) and https://doi.org/10.1594/PANGAEA.904405 (Sommer and Dengler, 2019b).

Supplement. The supplement related to this article is available online at: https://doi.org/10.5194/bg-17-3685-2020-supplement.

Author contributions. AP and FS conceived the study. AP, FS, AD and SS conducted the sampling at sea. AP analysed the trace metal concentrations with support from CS. AP and FS prepared the paper with contributions from all co-authors.

Competing interests. The authors declare that they have no conflict of interest.

Special issue statement. This article is part of the special issue "Ocean deoxygenation: drivers and consequences - past, present and future (BG/CP/OS inter-journal SI)". It is not associated with a conference.

Acknowledgements. We are grateful for the support from the crew of RV Meteor during the fieldwork. We thank Antje Beck, Anke Bleyer, Bettina Domeyer, Dominik Jasinski, Asmus Petersen, Tim Steffens, Regina Surberg and Matthias Türk for their technical and analytical assistance. This study was supported by the German Research Foundation through the Emmy Noether Nachwuchsforschergruppe ICONOX (Iron Cycling in Continental Margin Sediments and the Nutrient and Oxygen Balance of the Ocean) and Sonderforschungsbereich 754 (Climate-Biogeochemistry Interactions in the Tropical Ocean). We would also like to thank Edouard Metzger and one anonymous referee for their constructive reviews as well as Syed Wajih Ahmad Naqvi for the editorial handling of the paper.
Financial support. This research has been supported by the Deutsche Forschungsgemeinschaft (grant nos. ICONOX and SFB754).

The article processing charges for this open-access publication were covered by a Research Centre of the Helmholtz Association.

Review statement. This paper was edited by S. Wajih A. Naqvi and reviewed by Edouard Metzger and one anonymous referee.

\section{References}

Audry, S., Blanc, G., Schäfer, J., Chaillou, G. and Robert, S.: Early diagenesis of trace metals $(\mathrm{Cd}, \mathrm{Cu}, \mathrm{Co}, \mathrm{Ni}$, $\mathrm{U}, \mathrm{Mo}$, and $\mathrm{V}$ ) in the freshwater reaches of a macrotidal estuary, Geochim. Cosmochim. Ac., 70, 2264-2282, https://doi.org/10.1016/j.gca.2006.02.001, 2006.

Ball, J. W. and Nordstrom, D. K.: WATEQ4F - User's manual with revised thermodynamic data base and test cases for calculating speciation of major, trace and redox elements in natural waters, US Geol. Surv., (Open-File Rep.) 91-183, https://doi.org/10.3133/ofr90129, 1991.

Bianchi, D., Weber, T. S., Kiko, R., and Deutsch, C.: Global niche of marine anaerobic metabolisms expanded by particle microenvironments, Nat. Geosci., 11, 1-6, https://doi.org/10.1038/s41561018-0081-0, 2018.

Biller, D. V. and Bruland, K. W.: Sources and distributions of $\mathrm{Mn}, \mathrm{Fe}, \mathrm{Co}, \mathrm{Ni}, \mathrm{Cu}, \mathrm{Zn}$, and $\mathrm{Cd}$ relative to macronutrients along the central California coast during the spring and summer upwelling season, Mar. Chem., 155, 50-70, https://doi.org/10.1016/j.marchem.2013.06.003, 2013.

Böning, P., Brumsack, H. J., Böttcher, M. E., Schnetger, B., Kriete, C., Kallmeyer, J., and Borchers, S. L.: Geochemistry of Peruvian near-surface sediments, Geochim. Cosmochim. Ac., 68, 44294451, https://doi.org/10.1016/j.gca.2004.04.027, 2004.

Bopp, L., Le Quéré, C., Heimann, M., Manning, A. C. and Monfray, P.: Climate-induced oceanic oxygen fluxes: Implications for the contemporary carbon budget, Global Biogeochem. Cy., 16, 1022, https://doi.org/10.1029/2001GB001445, 2002.

Borchers, S. L., Schnetger, B., Böning, P., and Brumsack, H.-J.: Geochemical signatures of the Namibian diatom belt: Perennial upwelling and intermittent anoxia, Geochem. Geophy. Geosy., 6, Q06006, https://doi.org/10.1029/2004GC000886, 2005.

Boudreau, B. P.: Diagenetic Models and Their Implementation, Springer, 414 pp., 1997.

Boyd, P. W. and Ellwood, M. J.: The biogeochemical cycle of iron in the ocean, Nat. Geosci., 3, 675-682, https://doi.org/10.1038/ngeo964, 2010.

Bruland, K. W. and Lohan, M. C.: Controls of Trace Metals in Seawater, in Treatise on Geochemistry, Elsevier, 23-47, 2003.

Brumsack, H. J.: The trace metal content of recent organic carbon-rich sediments: Implications for Cretaceous black shale formation, Palaeogeogr. Palaeocl., 232, 344-361, https://doi.org/10.1016/j.palaeo.2005.05.011, 2006. 
Canfield, D. E.: Reactive iron in marine sediments, Geochim. Cosmochim. Ac., 53, 619-632, https://doi.org/10.1016/00167037(89)90005-7, 1989.

Carlson, H. K., Clark, I. C., Blazewicz, S. J., Iavarone, A. T., and Coates, J. D.: Fe(II) Oxidation Is an Innate Capability of NitrateReducing Bacteria That Involves Abiotic and Biotic Reactions, J. Bacteriol., 195, 3260-3268, https://doi.org/10.1128/JB.0005813, 2013.

Ciceri, G., Maran, C., Martinotti, W., and Queirazza, G.: Geochemical cycling of heavy metals in a marine coastal area: benthic flux determination from pore water profiles and in situ measurements using benthic chambers, Hydrobiologia, 235, 501-517, https://doi.org/10.1007/BF00026238, 1992.

Colbert, D., Coale, K., Berelson, W., and Johnson, K.: Cadmium Flux in Los Angeles/Long Beach Harbours and at Sites along the California Continental Margin, Estuar. Coast. Shelf Sci., 53, 169-180, https://doi.org/10.1006/ecss.2001.0802, 2001.

Collier, R. and Edmond, J.: The trace element geochemistry of marine biogenic particulate matter, Prog. Oceanogr., 13, 113-199, https://doi.org/10.1016/0079-6611(84)90008-9, 1984.

Conway, T. M. and John, S. G.: Quantification of dissolved iron sources to the North Atlantic Ocean, Nature, 511, 212-215, https://doi.org/10.1038/nature13482, 2014.

Conway, T. M. and John, S. G.: Biogeochemical cycling of cadmium isotopes along a high-resolution section through the North Atlantic Ocean, Geochim. Cosmochim. Ac., 148, 269-283, https://doi.org/10.1016/j.gca.2014.09.032, 2015a.

Conway, T. M. and John, S. G.: The cycling of iron, zinc and cadmium in the North East Pacific Ocean - Insights from stable isotopes, Geochim. Cosmochim. Ac., 164, 262-283, https://doi.org/10.1016/j.gca.2015.05.023, 2015b.

Dale, A. W., Nickelsen, L., Scholz, F., Hensen, C., Oschlies, A., and Wallmann, K.: A revised global estimate of dissolved iron fluxes from marine sediments, Global Biogeochem. Cy., 29, 691-707, https://doi.org/10.1002/2014GB005017, 2015a.

Dale, A. W., Sommer, S., Lomnitz, U., Montes, I., Treude, T., Liebetrau, V., Gier, J., Hensen, C., Dengler, M., Stolpovsky, K., Bryant, L. D., and Wallmann, K.: Organic carbon production, mineralisation and preservation on the Peruvian margin, Biogeosciences, 12, 1537-1559, https://doi.org/10.5194/bg-121537-2015, 2015b.

Dalsgaard, T., Thamdrup, B., Farías, L., and Revsbech, N. P.: Anammox and denitrification in the oxygen minimum zone of the eastern South Pacific, Limnol. Oceanogr., 57, 1331-1346, https://doi.org/10.4319/lo.2012.57.5.1331, 2012.

Davies-Colley, R. J., Nelson, P. O., and Williamson, K. J.: Sulfide control of cadmium and copper concentrations in anaerobic estuarine sediments, Mar. Chem., 16, 173-186, https://doi.org/10.1016/0304-4203(85)90021-0, 1985.

Dengler, M.: Hydrochemistry of water samples during METEOR cruise M92, PANGAEA, https://doi.org/10.1594/PANGAEA.862046, 2016.

Echevin, V., Colas, F., Espinoza-Morriberon, D., Vasquez, L., Anculle, T., and Gutierrez, D.: Forcings and Evolution of the 2017 Coastal El Niño Off Northern Peru and Ecuador, Front. Mar. Sci., 5, 1-16, https://doi.org/10.3389/fmars.2018.00367, 2018.

Ehlert, C., Doering, K., Wallmann, K., Scholz, F., Sommer, S., Grasse, P., Geilert, S., and Frank, M.: Stable silicon isotope signatures of marine pore waters - Biogenic opal dissolution versus authigenic clay mineral formation, Geochim. Cosmochim. Ac., 191, 102-117, https://doi.org/10.1016/j.gca.2016.07.022, 2016.

Elderfield, H., McCaffrey, R. J., Luedtke, N., Bender, M., and Truesdale, V. W.: Chemical diagenesis in Narragansett Bay sediments, Am. J. Sci., 281, 1021-1055, https://doi.org/10.2475/ajs.281.8.1021, 1981.

Elrod, V. A., Berelson, W. M., Coale, K. H., and Johnson, K. S.: The flux of iron from continental shelf sediments: A missing source for global budgets, Geophys. Res. Lett., 31, L12307, https://doi.org/10.1029/2004GL020216, 2004.

Fitzsimmons, J. N., Conway, T. M., Lee, J.-M., Kayser, R., Thyng, K. M., John, S. G., and Boyle, E. A.: Dissolved iron and iron isotopes in the southeastern Pacific Ocean, Global Biogeochem. Cy., 30, 1372-1395, https://doi.org/10.1002/2015GB005357, 2016.

Friedrich, J., Dinkel, C., Friedl, G., Pimenov, N., Wijsman, J., Gomoiu, M.-T., Cociasu, A., Popa, L., and Wehrli, B.: Benthic Nutrient Cycling and Diagenetic Pathways in the Northwestern Black Sea, Estuar. Coast. Shelf Sci., 54, 369-383, https://doi.org/10.1006/ecss.2000.0653, 2002.

Garreaud, R. D.: A plausible atmospheric trigger for the 2017 coastal El Niño, Int. J. Clim., 38, 1296-1302, https://doi.org/10.1002/joc.5426, 2018.

Gendron, A., Silverberg, N., Sundby, B., and Lebel, J.: Early diagenesis of cadmium and cobalt in sediments of the Laurentian Trough, Geochim. Cosmochim. Ac., 50, 741-747, https://doi.org/10.1016/j.ijmachtools.2007.10.013, 1986.

Gerringa, L. J. A.: Aerobic degradation of organic matter and the mobility of $\mathrm{Cu}, \mathrm{Cd}, \mathrm{Ni}, \mathrm{Pb}, \mathrm{Zn}, \mathrm{Fe}$ and $\mathrm{Mn}$ in marine sediment slurries, Mar. Chem., 29, 355-374, https://doi.org/10.1016/0304 4203(90)90023-6, 1990.

Gobeil, C., Silverberg, N., Sundby, B., and Cossa, D.: Cadmium diagenesis in Laurentian Trough sediments, Geochim. Cosmochim. Ac., 51, 589-596, https://doi.org/10.1016/00167037(87)90071-8, 1987.

Graco, M. I., Purca, S., Dewitte, B., Castro, C. G., Morón, O., Ledesma, J., Flores, G., and Gutiérrez, D.: The OMZ and nutrient features as a signature of interannual and low-frequency variability in the Peruvian upwelling system, Biogeosciences, 14, 4601-4617, https://doi.org/10.5194/bg-14-4601-2017, 2017.

Grasshoff, M., Erhardt, M., and Kremling, K.: Methods of seawater analysis, Wiley-VCH, Weinheim, 89, 505-505, https://doi.org/10.1002/ange.19770890738, 1999.

Gutiérrez, D., Enríquez, E., Purca, S., Quipúzcoa, L., Marquina, R., Flores, G., and Graco, M.: Oxygenation episodes on the continental shelf of central Peru: Remote forcing and benthic ecosystem response, Prog. Oceanogr., 79, 177-189, https://doi.org/10.1016/j.pocean.2008.10.025, 2008.

Hawco, N. J., Ohnemus, D. C., Resing, J. A., Twining, B. S., and Saito, M. A.: A dissolved cobalt plume in the oxygen minimum zone of the eastern tropical South Pacific, Biogeosciences, 13, 5697-5717, https://doi.org/10.5194/bg-13-5697-2016, 2016.

Heller, M. I., Lam, P. J., Moffett, J. W., Till, C. P., Lee, J. M., Toner, B. M., and Marcus, M. A.: Accumulation of Fe oxyhydroxides in the Peruvian oxygen deficient zone implies non-oxygen dependent Fe oxidation, Geochim. Cosmochim. Ac., 211, 174-193, https://doi.org/10.1016/j.gca.2017.05.019, 2017. 
Helm, K. P., Bindoff, N. L., and Church, J. A.: Observed decreases in oxygen content of the global ocean, Geophys. Res. Lett., 38, 1-6, https://doi.org/10.1029/2011GL049513, 2011.

Homoky, W. B., Severmann, S., McManus, J., Berelson, W. M., Riedel, T. E., Statham, P. J., and Mills, R. A.: Dissolved oxygen and suspended particles regulate the benthic flux of iron from continental margins, Mar. Chem., 134, 59-70, https://doi.org/10.1016/j.marchem.2012.03.003, 2012.

Hydes, D., Aoyama, M., Aminot, A., Bakker, K., Becker, S., Coverly, S., Daniel, A., Dickson, A. G., Grosso, O., Kerouel, R., van Ooijen, J., Sato, K., Tanhua, T., Woodward, E. M. S., and Zhang, J. Z.: Determination of dissolved nutrients (N, P, Si) in seawater with high precision and inter-comparability using gas-segmented continuous flow analysers, Go-sh. Repeat Hydrogr. Man. IOCCP Rep. A Collect, available at: http://archimer. ifremer.fr/doc/00020/13141/ (last access: 1 July 2020), Expert Reports Guidel., 134, 1-87, 2010.

Janssen, D. J., Conway, T. M., John, S. G., Christian, J. R., Kramer, D. I., Pedersen, T. F., and Cullen, J. T.: Undocumented water column sink for cadmium in open ocean oxygendeficient zones, P. Natl. Acad. Sci. USA, 111, 6888-6893, https://doi.org/10.1073/pnas.1402388111, 2014.

John, S. G., Helgoe, J., Townsend, E., Weber, T., DeVries, T., Tagliabue, A., Moore, K., Lam, P., Marsay, C. M., and Till, C.: Biogeochemical cycling of $\mathrm{Fe}$ and $\mathrm{Fe}$ stable isotopes in the Eastern Tropical South Pacific, Mar. Chem., 201, 66-76, https://doi.org/10.1016/j.marchem.2017.06.003, 2018.

Karstensen, J., Stramma, L., and Visbeck, M.: Oxygen minimum zones in the eastern tropical Atlantic and Pacific oceans, Prog. Oceanogr., 77, 331-350, https://doi.org/10.1016/j.pocean.2007.05.009, 2008.

Keeling, R. F., Körtzinger, A., and Gruber, N.: Ocean Deoxygenation in a Warming World, Ann. Rev. Mar. Sci., 2, 199-229, https://doi.org/10.1146/annurev.marine.010908.163855, 2010.

Klar, J. K., Schlosser, C., Milton, J. A., Woodward, E. M. S., Lacan, F., Parkinson, I. J., Achterberg, E. P., and James, R. H.: Sources of dissolved iron to oxygen minimum zone waters on the Senegalese continental margin in the tropical North Atlantic Ocean: Insights from iron isotopes, Geochim. Cosmochim. Ac., 236, 6078, https://doi.org/10.1016/j.gca.2018.02.031, 2018.

Klinkhammer, G., Heggie, D. T., and Graham, D. W.: Metal diagenesis in oxic marine sediments, Earth Planet. Sc. Lett., 61, 211219, https://doi.org/10.1016/0012-821X(82)90054-1, 1982.

Klueglein, N. and Kappler, A.: Abiotic oxidation of Fe(II) by reactive nitrogen species in cultures of the nitrate-reducing $\mathrm{Fe}(\mathrm{II})$ oxidizer Acidovorax sp. BoFeN1 - questioning the existence of enzymatic Fe(II) oxidation, Geobiology, 11, 180-190, https://doi.org/10.1111/gbi.12019, 2013.

Lam, P. and Kuypers, M. M. M.: Microbial Nitrogen Cycling Processes in Oxygen Minimum Zones, Ann. Rev. Mar. Sci., 3, 317-345, https://doi.org/10.1146/annurev-marine120709-142814, 2011.

Lam, P., Lavik, G., Jensen, M. M., van de Vossenberg, J., Schmid, M., Woebken, D., Gutierrez, D., Amann, R., Jetten, M. S. M., and Kuypers, M. M. M.: Revising the nitrogen cycle in the Peruvian oxygen minimum zone, P. Natl. Acad. Sci. USA, 106, 47524757, https://doi.org/10.1073/pnas.0812444106, 2009.
Lane, T. W. and Morel, F. M. M.: A biological function for cadmium in marine diatoms, P. Natl. Acad. Sci. USA, 97, 46274631, https://doi.org/10.1073/pnas.090091397, 2000.

Lee, J. and Morel, F.: Replacement of zinc by cadmium in marine phytoplankton, Mar. Ecol. Prog. Ser., 127, 305-309, https://doi.org/10.3354/meps127305, 1995.

Lenstra, W. K., Hermans, M., Séguret, M. J. M., Witbaard, R., Behrends, T., Dijkstra, N., van Helmond, N. A. G. M., Kraal, P., Laan, P., Rijkenberg, M. J. A., Severmann, S., Teaca, A., and Slomp, C. P.: The shelf-to-basin iron shuttle in the Black Sea revisited, Chem. Geol., 511, 314-341, https://doi.org/10.1016/j.chemgeo.2018.10.024, 2019.

Levin, L., Gutiérrez, D., Rathburn, A., Neira, C., Sellanes, J., Muñoz, P., Gallardo, V., and Salamanca, M.: Benthic processes on the Peru margin: a transect across the oxygen minimum zone during the 1997-98 El Niño, Prog. Oceanogr., 53, 1-27, https://doi.org/10.1016/S0079-6611(02)00022-8, 2002.

Li, Y.-H. and Gregory, S.: Diffusion of ions in sea water and in deep-sea sediments, Geochim. Cosmochim. Ac., 38, 703-714, https://doi.org/10.1016/0016-7037(74)90145-8, 1974.

Little, S. H., Vance, D., Lyons, T. W., and McManus, J.: Controls on trace metal authigenic enrichment in reducing sediments: Insights from modern oxygen-deficient settings, Am. J. Sci., 315, 77-119, https://doi.org/10.2475/02.2015.01, 2015.

Liu, X. and Millero, F. J.: The solubility of iron in seawater, Mar. Chem., 77, 43-54, https://doi.org/10.1016/S03044203(01)00074-3, 2002.

Lohan, M. C. and Bruland, K. W.: Elevated Fe(II) and dissolved Fe in hypoxic shelf waters off Oregon and Washington: An enhanced source of iron to coastal upwelling regimes, Environ. Sci. Technol., 42, 6462-6468, https://doi.org/10.1021/es800144j, 2008.

Metzger, E., Simonucci, C., Viollier, E., Sarazin, G., Prévot, F., Elbaz-Poulichet, F., Seidel, J.-L., and Jézéquel, D.: Influence of diagenetic processes in Thau lagoon on cadmium behavior and benthic fluxes, Estuar. Coast. Shelf Sci., 72, 497-510, https://doi.org/10.1016/j.ecss.2006.11.016, 2007.

Moore, C. M., Mills, M. M., Arrigo, K. R., Berman-Frank, I., Bopp, L., Boyd, P. W., Galbraith, E. D., Geider, R. J., Guieu, C., Jaccard, S. L., Jickells, T. D., La Roche, J., Lenton, T. M., Mahowald, N. M., Marañón, E., Marinov, I., Moore, J. K., Nakatsuka, T., Oschlies, A., Saito, M. A., Thingstad, T. F., Tsuda, A., and Ulloa, O.: Processes and patterns of oceanic nutrient limitation, Nat. Geosci., 6, 701-710, https://doi.org/10.1038/ngeo1765, 2013.

Morel, F. M. M., Milligan, A. J., and Saito, M. A.: Marine Bioinorganic Chemistry: The Role of Trace Metals in the Oceanic Cycles of Major Nutrients, in: Treatise on Geochemistry, Elsevier, 197, 123-150, 2014.

Morse, J. W. and Luther, G. W.: Chemical influences on trace metal-sulfide interactions in anoxic sediments, Geochim. Cosmochim. Ac., 63, 3373-3378, https://doi.org/10.1016/S00167037(99)00258-6, 1999.

Muñoz, P., Dezileau, L., Cardenas, L., Sellanes, J., Lange, C. B., Inostroza, J., Muratli, J., and Salamanca, M. A.: Geochemistry of trace metals in shelf sediments affected by seasonal and permanent low oxygen conditions off central Chile, SE Pacific $\left(\sim 36^{\circ} \mathrm{S}\right)$, Cont. Shelf Res., 33, 51-68, https://doi.org/10.1016/j.csr.2011.11.006, 2012. 
Noble, A. E., Lamborg, C. H., Ohnemus, D. C., Lam, P. J., Goepfert, T. J., Measures, C. I., Frame, C. H., Casciotti, K. L., DiTullio, G. R., Jennings, J., and Saito, M. A.: Basin-scale inputs of cobalt, iron, and manganese from the Benguela-Angola front to the South Atlantic Ocean, Limnol. Oceanogr., 57, 989-1010, https://doi.org/10.4319/lo.2012.57.4.0989, 2012.

Noffke, A., Hensen, C., Sommer, S., Scholz, F., Bohlen, L., Mosch, T., Graco, M., and Wallmann, K.: Benthic iron and phosphorus fluxes across the Peruvian oxygen minimum zone, Limnol. Oceanogr., 57, 851-867, https://doi.org/10.4319/lo.2012.57.3.0851, 2012.

Ohde, T.: Coastal Sulfur Plumes off Peru During El Niño, La Niña, and Neutral Phases, Geophys. Res. Lett., 45, 7075-7083, https://doi.org/10.1029/2018GL077618, 2018.

Olson, L., Quinn, K. A., Siebecker, M. G., Luther, G. W., Hastings, D., and Morford, J. L.: Trace metal diagenesis in sulfidic sediments: Insights from Chesapeake Bay, Chem. Geol., 452, 47-59, https://doi.org/10.1016/j.chemgeo.2017.01.018, 2017.

Oschlies, A., Schulz, K. G., Riebesell, U., and Schmittner, A.: Simulated 21st century's increase in oceanic suboxia by $\mathrm{CO}_{2}$ enhanced biotic carbon export, Global Biogeochem. Cy., 22, 110, https://doi.org/10.1029/2007GB003147, 2008.

Pakhomova, S. V., Hall, P. O. J., Kononets, M. Y., Rozanov, A. G., Tengberg, A., and Vershinin, A. V.: Fluxes of iron and manganese across the sediment-water interface under various redox conditions, Mar. Chem., 107, 319-331, https://doi.org/10.1016/j.marchem.2007.06.001, 2007.

Peng, Q., Xie, S.-P., Wang, D., Zheng, X.-T., and Zhang, H.: Coupled ocean-atmosphere dynamics of the 2017 extreme coastal El Niño, Nat. Commun., 10, 298, https://doi.org/10.1038/s41467018-08258-8, 2019.

Pennington, J. T., Mahoney, K. L., Kuwahara, V. S., Kolber, D. D., Calienes, R., and Chavez, F. P.: Primary production in the eastern tropical Pacific: A review, Prog. Oceanogr., 69, 285-317, https://doi.org/10.1016/j.pocean.2006.03.012, 2006.

Plass, A., Schlosser, C., Sommer, S., Dale, Achterberg, E. P., and Scholz, F.: Iron, cadmium and hydrogen sulfide data from nearbottom water, sediment pore water and benthic chamber incubations during METEOR cruises M136 and M137, PANGEA, available at: https://doi.org/10.1594/PANGAEA.918805, 2020.

Point, D., Monperrus, M., Tessier, E., Amouroux, D., Chauvaud, L., Thouzeau, G., Jean, F., Amice, E., Grall, J., Leynaert, A., Clavier, J., and Donard, O. F. X.: Biological control of trace metal and organometal benthic fluxes in a eutrophic lagoon (Thau Lagoon, Mediterranean Sea, France), Estuar. Coast. Shelf Sci., 72, 457471, https://doi.org/10.1016/j.ecss.2006.11.013, 2007.

Price, N. M. and Morel, F. M. M.: Cadmium and cobalt substitution for zinc in a marine diatom, Nature, 344, 658-660, https://doi.org/10.1038/344658a0, 1990.

Ragueneau, O., Tréguer, P., Leynaert, A., Anderson, R. F., Brzezinski, M. A., DeMaster, D. J., Dugdale, R. C., Dymond, J., Fischer, G., François, R., Heinze, C., Maier-Reimer, E., Martin-Jézéquel, V., Nelson, D. M., and Quéguiner, B.: A review of the Si cycle in the modern ocean: Recent progress and missing gaps in the application of biogenic opal as a paleoproductivity proxy, Glob. Planet. Change, 26, 317-365, https://doi.org/10.1016/S09218181(00)00052-7, 2000
Raiswell, R. and Canfield, D. E.: The Iron Biogeochemical Cycle Past and Present, Geochem. Perspect., 1, 1-220, https://doi.org/10.7185/geochempersp.1.1, 2012.

Rapp, I., Schlosser, C., Rusiecka, D., Gledhill, M., and Achterberg, E. P.: Automated preconcentration of $\mathrm{Fe}, \mathrm{Zn}, \mathrm{Cu}, \mathrm{Ni}, \mathrm{Cd}, \mathrm{Pb}$, $\mathrm{Co}$, and $\mathrm{Mn}$ in seawater with analysis using high-resolution sector field inductively-coupled plasma mass spectrometry, Anal. Chim. Ac., 976, 1-13, https://doi.org/10.1016/j.aca.2017.05.008, 2017.

Rapp, I., Schlosser, C., Menzel Barraqueta, J.-L., Wenzel, B., Lüdke, J., Scholten, J., Gasser, B., Reichert, P., Gledhill, M., Dengler, M., and Achterberg, E. P.: Controls on redox-sensitive trace metals in the Mauritanian oxygen minimum zone, Biogeosciences, 16, 4157-4182, https://doi.org/10.5194/bg-16-41572019, 2019.

Rickard, D., Griffith, A., Oldroyd, A., Butler, I. B., LopezCapel, E., Manning, D. A. C., and Apperley, D. C.: The composition of nanoparticulate mackinawite, tetragonal iron(II) monosulfide, Chem. Geol., 235, 286-298, https://doi.org/10.1016/j.chemgeo.2006.07.004, 2006

Rigaud, S., Radakovitch, O., Couture, R. M., Deflandre, B., Cossa, D., Garnier, C., and Garnier, J. M.: Mobility and fluxes of trace elements and nutrients at the sedimentwater interface of a lagoon under contrasting water column oxygenation conditions, Appl. Geochem., 31, 35-51, https://doi.org/10.1016/j.apgeochem.2012.12.003, 2013.

Rosenthal, Y., Lam, P., Boyle, E. A., and Thomson, J.: Precipitation and postdepositional mobility, Earth Planet. Sc. Lett., 132, 99111, https://doi.org/10.1016/0012-821X(95)00056-I, 1995.

Rue, E. L. and Bruland, K. W.: The role of organic complexation on ambient iron chemistry in the equatorial Pacific Ocean and the response of a mesoscale iron addition experiment, Limnol. Oceanogr., 42, 901-910, https://doi.org/10.4319/lo.1997.42.5.0901, 1997.

Saito, M. A., Goepfert, T. J., and Ritt, J. T.: Some thoughts on the concept of colimitation: Three definitions and the importance of bioavailability, Limnol. Oceanogr., 53, 276-290, https://doi.org/10.4319/lo.2008.53.1.0276, 2008.

Schlosser, C., Streu, P., Frank, M., Lavik, G., Croot, P. L., Dengler, M., and Achterberg, E. P.: $\mathrm{H}_{2} \mathrm{~S}$ events in the Peruvian oxygen minimum zone facilitate enhanced dissolved Fe concentrations, Sci. Rep., 8, 1-8, https://doi.org/10.1038/s41598-018-30580-w, 2018.

Schmidtko, S., Stramma, L., and Visbeck, M.: Decline in global oceanic oxygen content during the past five decades, Nature, 542, 335-339, https://doi.org/10.1038/nature21399, 2017.

Scholz, F. and Neumann, T.: Trace element diagenesis in pyrite-rich sediments of the Achterwasser lagoon, SW Baltic Sea, Mar. Chem., 107, 516-532, https://doi.org/10.1016/j.marchem.2007.08.005, 2007.

Scholz, F., Mcmanus, J., Mix, A. C., Hensen, C., and Schneider, R. R.: The impact of ocean deoxygenation on iron release from continental margin sediments, Nat. Geosci., 7, 433-437, https://doi.org/10.1038/ngeo2162, 2014.

Scholz, F., Löscher, C. R., Fiskal, A., Sommer, S., Hensen, C., Lomnitz, U., Wuttig, K., Göttlicher, J., Kossel, E., Steininger, R., and Canfield, D. E.: Nitrate-dependent iron oxidation limits iron transport in anoxic ocean regions, Earth Planet. Sc. Lett., 454, 272-281, https://doi.org/10.1016/j.eps1.2016.09.025, 2016. 
Scholz, F., Schmidt, M., Hensen, C., Eroglu, S., Geilert, S., Gutjahr, M., and Liebetrau, V.: Shelf-to-basin iron shuttle in the Guaymas Basin, Gulf of California, Geochim. Cosmochim. Ac., 261, 7692, https://doi.org/10.1016/j.gca.2019.07.006, 2019.

Schroller-Lomnitz, U., Hensen, C., Dale, A. W., Scholz, F., Clemens, D., Sommer, S., Noffke, A. and Wallmann, K.: Dissolved benthic phosphate, iron and carbon fluxes in the Mauritanian upwelling system and implications for ongoing deoxygenation, Deep Sea Res. I, 143, 70-84, https://doi.org/10.1016/j.dsr.2018.11.008, 2019.

Schunck, H., Lavik, G., Desai, D. K., Großkopf, T., Kalvelage, T., Löscher, C. R., Paulmier, A., Contreras, S., Siegel, H., Holtappels, M., Rosenstiel, P., Schilhabel, M. B., Graco, M., Schmitz, R. A., Kuypers, M. M. M., and LaRoche, J.: Giant Hydrogen Sulfide Plume in the Oxygen Minimum Zone off Peru Supports Chemolithoautotrophy, PLOS ONE, 8, https://doi.org/10.1371/journal.pone.0068661, 2013.

Scor Working Group: GEOTRACES - An international study of the global marine biogeochemical cycles of trace elements and their isotopes, Geochemistry, 67, 85-131, https://doi.org/10.1016/j.chemer.2007.02.001, 2007.

Severmann, S., McManus, J., Berelson, W. M., and Hammond, D. E.: The continental shelf benthic iron flux and its isotope composition, Geochim. Cosmochim. Ac., 74, 3984-4004, https://doi.org/10.1016/j.gca.2010.04.022, 2010.

Sommer, S., Linke, P., Pfannkuche, O., Schleicher, T., Schneider v. D, D., Reitz, A., Haeckel, M., Flögel, S., and Hensen, C.: Seabed methane emissions and the habitat of frenulate tubeworms on the Captain Arutyunov mud volcano (Gulf of Cadiz), Mar. Ecol. Prog. Ser., 382, 69-86, https://doi.org/10.3354/meps07956, 2009.

Sommer, S., Gier, J., Treude, T., Lomnitz, U., Dengler, M., Cardich, J., and Dale, A. W.: Depletion of oxygen, nitrate and nitrite in the Peruvian oxygen minimum zone cause an imbalance of benthic nitrogen fluxes, Deep-Sea Res. Pt. I, 112, 113-122, https://doi.org/10.1016/j.dsr.2016.03.001, 2016.

Sommer, S. and Dengler, M.: Hydrochemistry of water samples during METEOR cruise M136, PANGAEA, available at: https://doi.org/10.1594/PANGAEA.904404, 2019a.

Sommer, S. and Dengler, M.: Hydrochemistry of water samples during METEOR cruise M137, PANGAEA, available at: https://doi.org/10.1594/PANGAEA.904405, 2019b.

Stookey, L. L.: Ferrozine - a new spectrophotometric reagent for iron, Anal. Chem., 42, 779-781, https://doi.org/10.1021/ac60289a016, 1970.

Stramma, L., Johnson, G. C., Sprintall, J., and Mohrholz, V.: Expanding Oxygen-Minimum Zones in the Tropical Oceans, Science, 320, 655-658, https://doi.org/10.1126/science.1153847, 2008.

Stramma, L., Schmidtko, S., Levin, L. A., and Johnson, G. C.: Ocean oxygen minima expansions and their biological impacts, Deep-Sea Res. Pt. I, 57, 587-595, https://doi.org/10.1016/j.dsr.2010.01.005, 2010.

Straub, K. L., Benz, M., Schink, B., and Widdel, F.: Anaerobic, nitrate-dependent microbial oxidation of ferrous iron, Appl. Environ. Microb., 62, 1458-1460, 1996.
Sunda, W. G. and Huntsman, S. A.: Effect of Zn, Mn, and $\mathrm{Fe}$ on $\mathrm{Cd}$ accumulation in phytoplankton: Implications for oceanic Cd cycling, Limnol. Oceanogr., 45, 1501-1516, https://doi.org/10.4319/lo.2000.45.7.1501, 2000.

Sundby, B., Martinez, P., and Gobeil, C.: Comparative geochemistry of cadmium, rhenium, uranium, and molybdenum in continental margin sediments, Geochim. Cosmochim. Ac., 68, 2485-2493, https://doi.org/10.1016/j.gca.2003.08.011, 2004.

Taylor, S. R. and McLennan, S. M.: Planetary crusts: Their composition, origin and evolution, edited by: Stuart, R. T. and Scott, M. M., Meteorit. Planet. Sci., 44, 465-466, https://doi.org/10.1111/j.1945-5100.2009.tb00744.x, 2009.

Thamdrup, B., Dalsgaard, T., and Revsbech, N. P.: Widespread functional anoxia in the oxygen minimum zone of the Eastern South Pacific, Deep-Sea Res. Pt. I, 65, 36-45, https://doi.org/10.1016/j.dsr.2012.03.001, 2012.

Turetta, C., Capodaglio, G., Cairns, W., Rabar, S., and Cescon, P.: Benthic fluxes of trace metals in the lagoon of Venice, Microchem. J., 79, 149-158, https://doi.org/10.1016/j.microc.2004.06.003, 2005.

Twining, B. S. and Baines, S. B.: The Trace Metal Composition of Marine Phytoplankton, Ann. Rev. Mar. Sci., 5, 191-215, https://doi.org/10.1146/annurev-marine-121211-172322, 2013.

Vedamati, J., Goepfert, T., and Moffett, J. W.: Iron speciation in the eastern tropical south pacific oxygen minimum zone off peru, Limnol. Oceanogr., 59, 1945-1957, https://doi.org/10.4319/lo.2014.59.6.1945, 2014.

Westerlund, S. F. G., Anderson, L. G., Hall, P. O. J., Iverfeldt, A., Van Der Loeff, M. M. R., and Sundby, B.: Benthic fluxes of cadmium, copper, nickel, zinc and lead in the coastal environment, Geochim. Cosmochim. Ac., 50, 12891296, https://doi.org/10.1016/0016-7037(86)90412-6, 1986.

Xie, R. C., Rehkämper, M., Grasse, P., van de Flierdt, T., Frank, M., and Xue, Z.: Isotopic evidence for complex biogeochemical cycling of $\mathrm{Cd}$ in the eastern tropical South Pacific, Earth Planet. Sc. Lett., 512, 134-146, https://doi.org/10.1016/j.eps1.2019.02.001, 2019.

Xu, Y., Feng, L., Jeffrey, P. D., Shi, Y., and Morel, F. M. M.: Structure and metal exchange in the cadmium carbonic anhydrase of marine diatoms, Nature, 452, 56-61, https://doi.org/10.1038/nature06636, 2008.

Yücel, M., Sommer, S., Dale, A. W., and Pfannkuche, O.: Microbial sulfide filter along a benthic redox gradient in the Eastern Gotland Basin, Baltic Sea, Front. Microb., 8, 1-16, https://doi.org/10.3389/fmicb.2017.00169, 2017.

Zago, C., Capodaglio, G., Ceradini, S., Ciceri, G., Abelmoschi, L., Soggia, F., Cescon, P., and Scarponi, G.: Benthic fluxes of cadmium, lead, copper and nitrogen species in the northern Adriatic Sea in front of the River Po outflow, Italy, Sci. Total Environ., 246, 121-137, https://doi.org/10.1016/S0048-9697(99)00421-0, 2000.

Zumft, W. G.: Cell biology and molecular basis of denitrification, Microbiol. Mol. Biol. Rev., 61, 533-616, 1997. 